\title{
In silico and in vitro cytotoxic effect of prodigiosin-conjugated silver nanoparticles on liver cancer cells (HepG2)
}

\author{
AHMEd I. El-BATAL ${ }^{1}$, HodA H. El-HeNDAWY ${ }^{2}$, AHMED H. I. FARAaG ${ }^{2,3,4 *}$ \\ ${ }^{1}$ Drug Radiation Research Department, Biotechnology Division, National Center for Radiation Research and Technology (NCRRT), \\ Atomic Energy Authority, Cairo, Egypt \\ ${ }^{2}$ Botany and Microbiology Department, Faculty of Science, Helwan University, Cairo, Egypt \\ ${ }^{3}$ Bioinformatics Center, Faculty of Science, Helwan University, Cairo, Egypt \\ ${ }^{4}$ Nanotechnology Center, Helwan University, Cairo, Egypt
}

\begin{abstract}
This study demonstrates a novel approach for the synthesis of silver nanoparticles (AgNPs) against human liver cancer cell line (HepG2) using prodigiosin pigment isolated from Serratia marcescens. It further investigates the influence of various parameters such as initial $\mathrm{pH}$, temperature, silver nitrate $\left(\mathrm{AgNO}_{3}\right)$ concentration, and prodigiosin concentration on stability and optical properties of synthesized prodigiosin AgNPs. Highly stable, spherical prodigiosin-conjugated AgNPs were synthesized with a mean diameter of $9.98 \mathrm{~nm}$ using a rapid one-step method. The cytotoxic activity investigated in the present study indicated that prodigiosin and prodigiosin-conjugated AgNPs possessed a strong cytotoxic potency against human liver cancer. The in silico molecular docking results of prodigiosin and prodigiosin-conjugated AgNPs are congruent with the in vitro studies and these AgNPs can be considered as good inhibitors of mitogen-activated protein kinase 1 (MEK kinases). The study opened the possibility of using prodigiosin-conjugated AgNPs to increase the efficiency of liver cancer treatment.
\end{abstract}

Key words: silver nanoparticles, cytotoxic activity, Serratia marcescens, in silico, prodigiosin

\section{Introduction}

Biological metallic synthesis of nanoparticles is a green ecofriendly technology since it neither involves harmful chemicals nor high temperatures (Sastry et al., 2003; Bhattacharya and Gupta, 2005; Durán et al., 2007; Gade et al., 2008; Mukherjee et al., 2008; Fayaz et al., 2010; Thakkar et al., 2010; Narayanan and Sakthivel, 2011; Rubilar et al., 2013). A wide spectrum of biological, chemical, and physical applications of biosynthesized nanoparticles covers, among others, drug delivery, cancer and gene therapy, DNA analysis, antiviral, antibacterial, and antifungal agents, diagnostic devices, anticoagulant, thrombolytic, and nanocatalysis (Gong et al., 2007; Li et al., 2011; Manikprabhu and Lingappa, 2014; Azeez et al., 2016; Ojo et al., 2016; Lateef et al., 2016a, 2016b, 2017). Nanoparticles of desired shapes and sizes can be obtained by controlling the synthesis conditions.
In the same regard, temperature and $\mathrm{pH}$ are reported to control AgNPs size in the supernatant of $E$. coli (Gurunathan et al., 2009a, 2009b; Ganesh Babu and Gunasekaran, 2009, 2013).

The most significant goals of cancer therapy research include the recognition of novel targets and the discovery of more specific chemotherapeutic agents. Prodigiosin is a family of natural red pigments produced by various bacteria including Gram-negative rods such as Serratia marcescens (Bunting, 1940; Weiss, 1949; Hubbard and Rimington, 1950; Castro et al., 1959; Williams et al., 1956; Rapoport and Holden, 1962; Khanafari et al., 2006), Pseudomonas magneslo rubra (Gerber, 1975), Vibrio psychroerythrous (D'Aoust and Gerber, 1974), Serratia rubidaea (Gargallo-Viola, 1989), Vibrio gazogenes (Allen et al., 1983), Alteromonas rubra (Gerber and Gauthier, 1979), Rugamonas rubr (Maurice, 2002),

\footnotetext{
* Corresponding author: Botany and Microbiology Department, Faculty of Science, Helwan University, 11795, Cairo, Egypt; e-mail: professor.ahmed85@gmail.com
} 
Hahella chejuensis (Huh et al., 2007; Kim et al., 2008); and Gram-positive actinomycetes such as Streptoverticillium rubrireticuli (Gerber and Stahly, 1975), Streptomyces griseoviridis (Kawasaki et al., 2008), Streptomyces longisporus Ruber (Wasserman et al., 1969), and Streptomyces coelicolor A3(2) (Harris et al., 2004). Prodigiosin, a bacterial metabolite, is a tripyrrole nitrogen ring pigment synthesized by Serratia marcescens (Williams, 1973; Kavitha et al., 2010). This red pigment is a promising drug owing to its antimicrobial and immunomodulatory activities (Lee et al., 1995; Da Silva Melo et al., 2000). It is produced by Serratia marcescens following a bifurcated biosynthesis pathway in which the separately obtained mono and bipyrrole precursors are coupled to form the linear tripyrrole red pigment (Boger and Patel, 1988) during the stationary phase of bacterial growth (Rokem and Weitzman, 1987). Serratia pigment genes clusters contain 14 genes common to Serratia which are named from pigA to pigN (Cerdeño et al., 2001; Harris et al., 2004). The cytotoxic properties of prodigiosin were recognized for several decades. Fullan and coworkers (1977) observed the antitumor activity of prodigiosin in mice. Some cancer chemotherapeutic agents act primarily by inflicting apoptotic death in susceptible cancer cells. Each of these chemotherapeutic agents interacts with a specific target, causing susceptible cancer cells to undergo apoptosis (Hannun, 1997). Prodigiosin quickly and powerfully triggers the cell death in hematopoietic cancer cells, human breast carcinoma cell lines (Pan et al., 2012), gastric cancer cell line HGT-1 (Díaz-Ruiz et al., 2001), human colon cancer cells (Montaner and Perez-Tomas, 2001), and lung cancer cell lines (Llagostera et al., 2005). However, nonmalignant cells showed no marked toxicity (Montaner et al., 2000). Prodigiosin is also shown to possess cytotoxic activity against human tumor-derived cell lines (Pandey et al., 2007; Venil, 2009). Suppression of cell proliferation, as well as initiation of cell death, was recognized in these cell lineages. In vitro anticancer activity was also described for different analogs and synthetic indole derivatives of prodigiosin (Pandey et al., 2007). Prodigiosin pigment showed antiproliferative and cytotoxic effects in both cultured tumor cell lines and human primary cancer cells (Campàs et al., 2003).

Liver cancer (hepatocellular carcinoma) is the third most frequent cause of death in malignant neoplastic disease and the estimated percentage of death rate is increasing in most of the developing countries (Siegel et al., 2013; Ashokkumar et al. 2014). In addition, prodigiosin also exhibited cytotoxic activity to doxorubicin (DOX)-resistant human small cell lung carcinoma cells and overexpressing multidrug resistance-related proteins (Llagostera et al., 2005; Venil, 2009). Cycloprodigiosin hydrochloride displayed a high cytotoxic potency against liver cancer cells, without any toxicity to normal cells, and its cost-effectiveness as a hepatocellular carcinoma drug increased the possibility of its therapeutic use (Yamamoto et al., 1999). The aim of this study was to investigate the possible use of prodigiosin pigment as a stabilizing, reducing, and coating agent for AgNPs synthesis, and to evaluate the cytotoxic effect of as-prepared AgNPs in human liver cancer cells (HepG2). It was demonstrated that the biological pigments, including those synthesized by bacteria, can be used for green synthesis of nanoparticles (Apte et al., 2013; Nair et al., 2013; Adelere and Lateef, 2016; Manikprabhu and Lingappa, 2013a, 2013b, 2014).

\section{Materials and methods}

\section{Bacterial isolate}

Serratia marcescens WSE was isolated from irrigation water collected from Almaryoteia Canal, Giza Governorate, Egypt. The bacterial culture was maintained on nutrient agar (NA) slant at $28^{\circ} \mathrm{C}$ for $24 \mathrm{~h}$ prior to storage at $4{ }^{\circ} \mathrm{C}$ for subsequent studies. The stored bacterial culture was subcultured monthly to maintain bacterial viability.

\section{Preparation, extraction, purification, and quantification of prodigiosin}

Prodigiosin extraction was carried out as described by Pradeep and coworkers (2013). A loop full of Serratia marcescens WSE grown on NA plates was inoculated into a $250 \mathrm{ml}$ flask with $50 \mathrm{ml}$ nutrient broth (NB) containing $5.0 \mathrm{~g} / 1$ peptone and $3.0 \mathrm{~g} / 1$ beef extract supplemented with $5 \mathrm{mg} / \mathrm{ml} \mathrm{L-tyrosine} \mathrm{and} \mathrm{was} \mathrm{incubated} \mathrm{in}$ a shaking incubator (VS-8480 SRN, Korea) at $3 \mathrm{rcf}$ and $28^{\circ} \mathrm{C}$ for $24 \mathrm{~h}$. A $10 \mathrm{ml}$ portion of the culture broth was centrifuged (Centurion Scientific K3 Series Centrifuges) at $4032 \mathrm{rcf}$ and $4{ }^{\circ} \mathrm{C}$ for $15 \mathrm{~min}$. Prodigiosin was extracted from the cell pellet as described by Pradeep and coworkers (2013). The cell pellet was resuspended in $10 \mathrm{ml}$ of $95 \%$ ethanol, and the extract was further processed by sonication using an ultrasonic homogenizer 
(BioLogics Ultrasonic Homogenizer Model 150VT; BioLogics Inc, Manassas, VA, USA). Sonication time and pulsar rate were adjusted at $40 \%$ pulsed power and $30 \%$ pulsar rate for 3 min until the solution became colorless. The mixture was vortexed and the suspension was centrifuged at $4032 \mathrm{rcf}$ and $4{ }^{\circ} \mathrm{C}$ for $10 \mathrm{~min}$ (Slater et al. 2003). It was then filter sterilized through a $0.45-\mu \mathrm{m}$ Whatman ${ }^{\circledR}$ Optitran ${ }^{\circledR}$ reinforced nitrocellulose membrane filter. The extracted pigment was transferred into a round-bottom flask (Schott Duran, Germany), and then evaporated using vacuum rotary evaporator (Heidolph WB 2000 , Germany) at $50^{\circ} \mathrm{C}$, the dry weight was then determined according to the protocol given by Garg and coworkers (2013). The extracted prodigiosin was applied to a thin layer chromatography (TLC) plate using a mixture of chloroform and methanol $(9: 1)$ as the solvent system for further purification (Casullo de Araújo et al., 2010). Prodigiosin was also passed through silica gel column chromatography $(2.5 \times 30 \mathrm{~cm}$; Kieselgel 60; Merck, Darmstadt, Germany, mesh size: 60-80) (Montaner and Pérez-Tomás, 2002) to separate the colorless impurities. The dried sample was dissolved in $5 \mathrm{ml}$ of $n$-hexane and loaded onto a silica gel column with an $n$-hexane and ethyl acetate solvent system $(2: 0 ; \mathrm{v} / \mathrm{v}$ to $0: 2 ; \mathrm{v} / \mathrm{v}$ ) at $1 \mathrm{ml} / \mathrm{min}$ flow rate. Chromatographic separation through high-performance liquid chromatography (HPLC) was carried out using a C18 column for reverse phase chromatography (Eclipse plus $\mathrm{C} 18,4.6 \times 100 \mathrm{~mm}$ ), with $0.8 \mathrm{ml} / \mathrm{min}$ flow rate and $10 \mu \mathrm{l}$ injection volume. Mobile phase was acetonitrile/HPLC water (60:40, v/v). The amount of pigment produced in bacterial cells and supernatant was determined by addition of $100 \mu \mathrm{l}$ of $0.1 \mathrm{~N} \mathrm{HCl}$ to $10 \mathrm{ml}$ of the supernatant and also by ethanolic extraction (Faraag et al., 2017). The total pigment was estimated by Spekwin32 optical spectroscopy software. Prodigiosin concentration was calculated by measuring the absorbance at $535 \mathrm{~nm}$ (Chen et al., 2006) using an extinction coefficient as $51.3 \times 10^{3}\left(1 \mathrm{~mol}^{-1} \mathrm{~cm}^{-1}\right)$ (Williams et al., 1961, 1971). Concentration of the total pigment yield (mol/l) was calculated using Spekwin32 version 1.71.6 (Menges, 2011).

\section{Synthesis of AgNPs using prodigiosin}

Prodigiosin was diluted with deionized water to a pigment final concentration of $4 \mu \mathrm{g} / \mathrm{ml}$, followed by the addition of the aqueous $\mathrm{AgNO}_{3}$ solution to $1 \mathrm{mM}$ final concentration. Finally, the volume was adjusted to $10 \mathrm{ml}$ with deionized water $(\mathrm{dd})$. The reaction was carried out at $20^{\circ} \mathrm{C}$ for $24 \mathrm{~h}$.

\section{Factors controlling the size and shape of synthesized AgNPS}

\section{Initial pH}

AgNPs were synthesized at a $\mathrm{pH}$ value adjusted over the range between 6 and 13. As previously mentioned, the synthesis was carried out using prodigiosin pigment with $1 \mathrm{mM} \mathrm{AgNO}$. The $\mathrm{pH}$ value was adjusted with 0.1 $\mathrm{N} \mathrm{HNO}_{3}$ and $0.1 \mathrm{~N} \mathrm{NaOH}$.

\section{Temperature}

The effect of temperature on AgNPs synthesis was observed over a range of temperatures from 10 to $100^{\circ} \mathrm{C}$. Synthesis of AgNPs at optimum $\mathrm{pH}$ was determined in a previous step.

\section{Silver nitrate concentration}

Various concentrations of $\mathrm{AgNO}_{3}$, ranging from 1 to $10 \mathrm{mM}$ in test tubes containing $4 \mu \mathrm{g} / \mathrm{ml}$ prodigiosin, were used to determine the effect of $\mathrm{AgNO}_{3}$ concentration on the synthesis of AgNPs. The volumes were adjusted to $10 \mathrm{ml}$ with dd $\mathrm{H}_{2} \mathrm{O}$. The reactions were incubated at $30^{\circ} \mathrm{C}$ and $\mathrm{pH} 13$ for $24 \mathrm{~h}$. Formation of AgNPs was confirmed by UV-visible spectrophotometry.

\section{Prodigiosin concentration}

The effect of different prodigiosin concentrations $(1,2,3,4,5,10,100,200,300$, and $500 \mu \mathrm{g} / \mathrm{ml})$ on the synthesis of Ag nanoparticles was examined using $\mathrm{AgNO}_{3}$ at its optimum concentration and $\mathrm{pH}$ value determined at previous experimental stages, incubated at $30^{\circ} \mathrm{C}$ for $24 \mathrm{~h}$.

\section{Time evolutions for synthesis of AgNPs}

The time evolutions for the synthesis of AgNPs were studied at regular intervals of $20 \mathrm{~min}$ for $2 \mathrm{~h}$, and then after $18 \mathrm{~h}$, as previously mentioned. The visualized color change to dark brown was observed in the reaction mixture and confirmed using UV-VIS spectrophotometry along with the other methods of characterization.

\section{Characterization of the synthesized AgNPs - UV-VIS spectral analysis}

AgNPs were characterized according to the protocol by El-Batal and coworkers (2013) as follows: UV-VIS spectroscopy analysis was carried out using a JASCO V-630 UV-VIS spectrophotometer (Pgeneral, China), where the maximum absorption spectra were analyzed 
over a range of $200-800 \mathrm{~nm}$, at a resolution of $1 \mathrm{~nm}$, and a scan speed of $400 \mathrm{~nm} / \mathrm{min}$ (El-Batal et al., 2013). Baseline correction of the spectrophotometer was carried out using a blank reference. The UV-VIS absorption spectra of all the samples were recorded and numerical data were plotted and analyzed by the Spekwin32 version 1.71.6.1 (Ramezani et al., 2008; Menges, 2011).

\section{Dynamic light scattering}

Average particle size and size distribution of dissolved nanoparticles were analyzed by dynamic light scattering (DLS) (PSS-NICOMP 380-ZLS particle sizing system St. Barbara, California, USA). The samples were diluted 10 times with deionized water before measurements and $250 \mu \mathrm{l}$ of suspensions were transferred to disposable low volume cuvettes. After equilibration at $25^{\circ} \mathrm{C}$ for 2 min, 5 measurements of each sample were taken using 12 runs of 10 s each (Poole and Owens, 2003; Kohler and Fritzsche, 2004).

\section{Transmission electron microscopy analysis}

Transmission electron microscopy (TEM) studies were performed using (JEOL Electron Microscopy JEM$100 \mathrm{CX}, \mathrm{FEI}$, America) electron microscope operating at an accelerating voltage of $200 \mathrm{KV}$. For TEM measurements, a drop of the resulting solution was placed on a copper grid covered with amorphous carbon. After allowing the film to stand for $2 \mathrm{~min}$, the extra solution was removed with blotting paper and the grid was allowed to air dry before the measurement (Poole and Owens, 2003).

\section{Fourier transform infrared spectroscopy spectral analysis}

Fourier transform infrared (FTIR) measurements were carried out to obtain information about the stabilizing chemical groups present around AgNPs and to understand the transformation of functional groups due to the reduction process. The resulting solutions were diluted with potassium bromide $(\mathrm{KBr})$ in a 1:100 ratio, and after drying at room temperature they were compressed to form disks to be analyzed further by FTIR spectra (4000-400 $\mathrm{cm}^{-1}$ ), at JASCO FT-IR-3600 (Bruker, Germany), by employing the $\mathrm{KBr}$ pellet technique at a $4 \mathrm{~cm}^{-1}$ resolution (Anderson et al., 2004; Hesse et al., 2008).

\section{$X$-ray diffraction pattern of AgNPs}

The AgNPs were investigated by X-ray diffraction (XRD) technique (6000, Shimadzu, Japan) using copper potassium alpha $(\mathrm{CuK} \alpha)$ radiations (Kohler and Fritzsche, 2004). AgNPs solution was placed on a glass slide to form a film and was dried at room temperature. In the next step a scan was performed using XRD operating with a $\mathrm{Cu}$ anode at $40.0(\mathrm{kV})$ voltage and $30.0 \mathrm{~mA}$ current, in the $2 \theta$ range value, between $20^{\circ}$ and $100^{\circ}$, with a speed of $2 \%$ min and continuous scan mode (Duane et al., 1997). Each diffraction peak was corrected for background scattering and was stripped of $\mathrm{K} \alpha 2$ portions of the diffracted intensity.

\section{Cytotoxicity assay for anticancer-drug screening}

AgNPs were dried using silica gel as a desiccant in a desiccation chamber. Cytotoxicity assay for anticancerdrug screening was carried out with sulforodamine B (SRB) assay according to a procedure by Skehan and coworkers (1990). Cells were seeded in 96 well microliter plates at 1000-2000 cells/well concentration in $100 \mu \mathrm{l}$. After $24 \mathrm{~h}$, cells were incubated for $72 \mathrm{~h}$ with various concentrations of drugs ( $10 \mathrm{mM}$ stocks of prodigiosin and nanosilver: $10 \mathrm{mM}$ stock DOX), and then 10fold serial dilutions $(0,0.01,0.1,1,10$, and 100 unit) were prepared. The plates were incubated for $48 \mathrm{~h}$, then the medium was discarded and cold trichloroacetic acid was added per $150 \mu \mathrm{l}$ well to $10 \%$ final concentration and incubated for $1 \mathrm{~h}$ at $4{ }^{\circ} \mathrm{C}$ for cell fixation. The cells were washed three times with sterile distilled water (TCA reduces SRB protein binding). The wells were then stained for 10-30 min at room temperature with $0.4 \%$ SRB dissolved in $1 \%$ acetic acid ( $70 \mu \mathrm{l} /$ well) and kept in the dark. They were washed with $1 \%$ acetic acid to remove the unbound dye until the washing solution was colorless. The plates were air dried $(24 \mathrm{~h})$. The dye was solubilized with $150 \mu \mathrm{l} /$ well $10 \mathrm{mM}$ tris-base (pH 7.4) for 5 min on a shaker, at $287 \mathrm{rcf}$. The optical density (OD) of each well was measured spectrophotometrically at 545 or $540 \mathrm{~nm}$ with an ELISA microplate reader (Skehan et al., 1990). The $\mathrm{IC}_{50}$ values were calculated using sigmoidal concentration response curve fitting models (Sigmaplot software).

\section{In silico docking study of cytotoxic activity}

The docking study was carried out on an Intel DualCore $(1.8 \mathrm{GHz})$ Windows PC with Molegro Virtual Docker (MVD) 2013.6.0.0 (Thomsen and Christensen 2006). The two-dimensional structure of prodigiosin conjugated with silver was converted into a three-dimensional for- 
mat for docking purposes using ChemOffice 2010 (CambridgeSoft Corporation). Prodigiosin and DOX ligands were obtained from PubChem Bioassay. Crystallographic structure of MEK1 kinase (Mitogen-activated protein kinase kinase) was obtained from the protein data bank [(4LMN-PDB) Research Collaboratory for Structural Bioinformatics (RCSB) (http://www.rcsb.org/pdb)]. The protein originated from Homo sapiens. Its resolution was $2.80 \AA$ with $0.2884 R$-value (Hatzivassiliou et al., 2013). The binding sites of the protein were determined using MVD and 5 cavities having $469.504 \AA^{3}$ total volume and $1111.04 \AA^{2}$ surface area were predicted. The binding site was set inside a restriction sphere of $15 \AA$ radius using MVD. All other software parameters for docking were set to the default values. The parameters were as follow: The "MolDock SE" searching algorithm was used with the number of runs set to 10 using a maximum of 1500 iterations and a total population size of 50 . The energy threshold used for the minimized final orientation was 100 . The Simplex evaluation with 300 maximum steps of neighbor distance factor 1 was completed. The chosen cavity was further refined using side-chain minimization by selecting the add-visible option at a maximum (10000) of steps per residue and a maximum (10000) of global steps. The setup for side-chain flexibility by selection of the add-visible option, setting for the selected flexible side chain during the docking option, and other parameters were all kept in default. All docking calculations were carried out using the gridbased MolDock score (GRID) function with 0.30 Å grid resolution.

\section{Results}

\section{Synthesis of AgNPs using prodigiosin pigments - effect of initial pH value on the synthesis of AgNPs}

The effect of initial $\mathrm{pH}$ value of prodigiosin aqueous solution is an important parameter in the synthesis of AgNPs. That parameter was studied at different $\mathrm{pH}$ values ranging from 6 to 13. Figure 1 shows that the absorption spectra of AgNPs with surface plasmon resonance (SPR) band blue-shifted due to an increase in the $\mathrm{pH}$ value from 9 to 13 and showed a maximum absorbance at $\mathrm{pH} 13$. Interestingly, at $\mathrm{pH}$ values ranging from 6 to 8 , the absorption peaks could not be observed indicating that AgNPs synthesis was not initiated in a solution having $\mathrm{pH}$ value below 9 . As the $\mathrm{pH}$ value increased

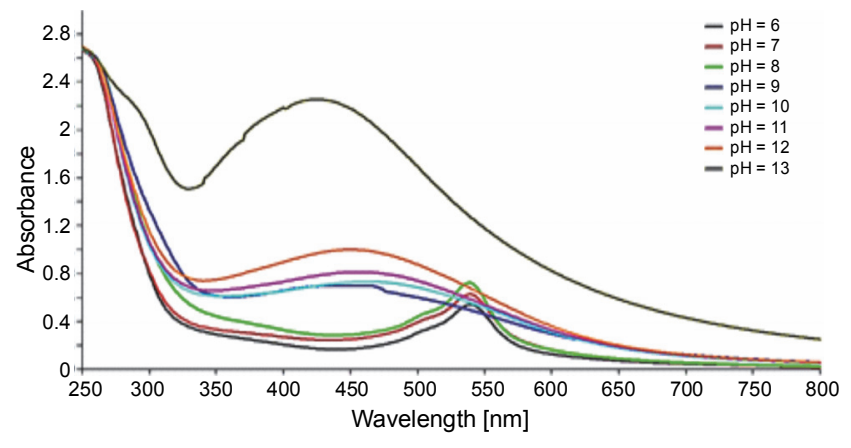

Fig. 1. UV-VIS spectra of AgNPs synthesized by prodigiosin at $\mathrm{pH}$ value ranging from 6 to 13
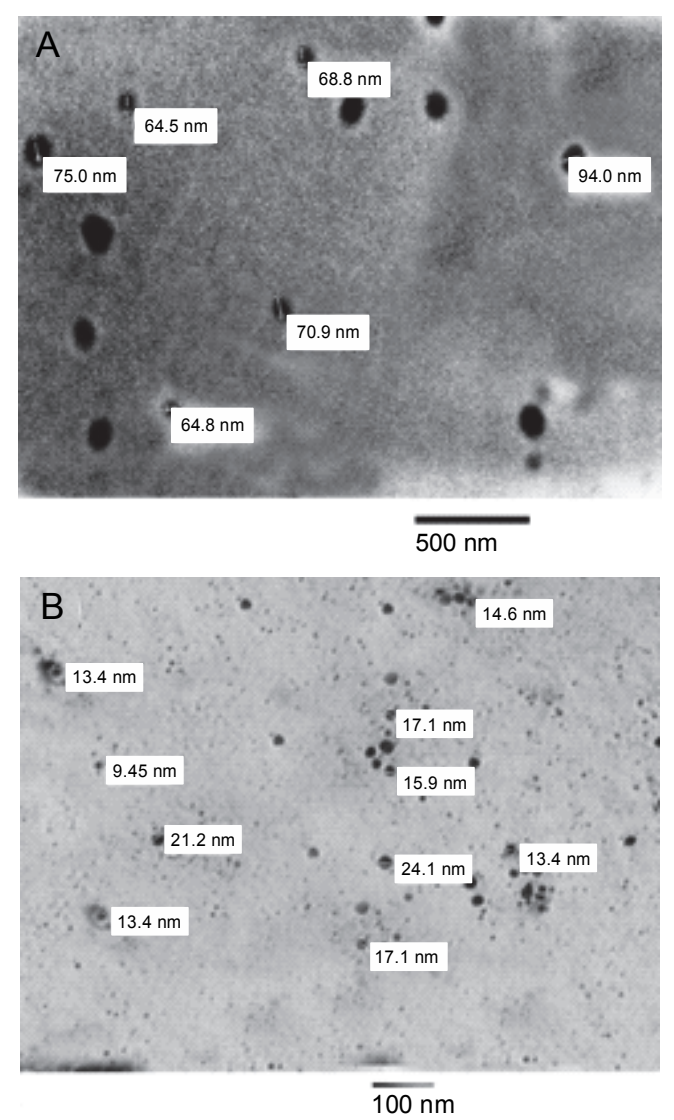

Fig. 2. TEM micrographs of AgNPs synthesized at A) $\mathrm{pH} 9$ and $\mathrm{B}) \mathrm{pH} 13$

the SPRs blue-shifted and absorbance intensity increased; however, the size of AgNPs reduced. TEM images of synthesized AgNPs by prodigiosin showed spherical nanoparticles with a mean size of $11.26 \mathrm{~nm}$ at $\mathrm{pH} 13$, and a mean size of $73.0 \mathrm{~nm}$ at pH 9 (Fig. 2).

\section{Effect of temperature on the synthesis of AgNPs}

The effect of temperature on the formation of AgNPs was also investigated. All the reaction temperatures sho- 


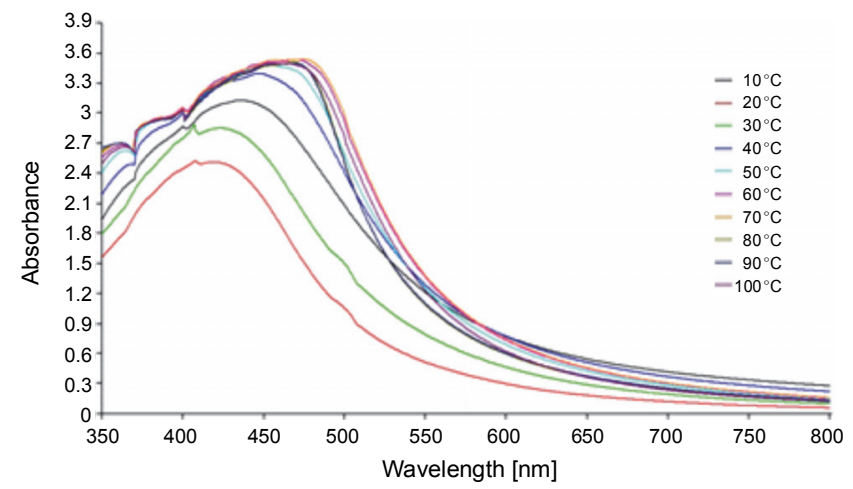

Fig. 3. UV-VIS spectra of AgNPs synthesized by prodigiosin at different temperatures
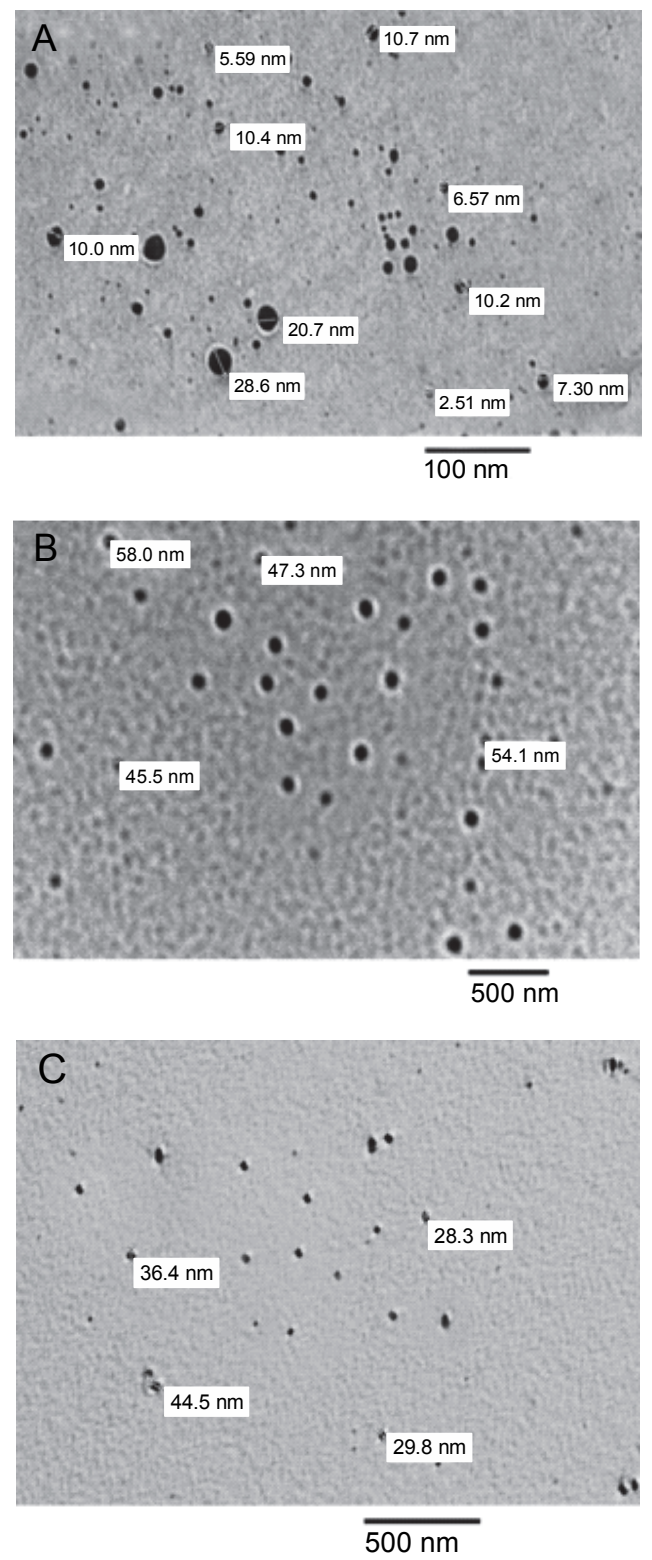

Fig. 4. TEM micrographs of AgNPs synthesized using $4 \mu \mathrm{g} / \mathrm{ml}$ prodigiosin at $\mathrm{pH} 13$ and $1 \mathrm{mM} \mathrm{AgNO}_{3}$ after $24 \mathrm{~h}$ at different temperatures A) $30^{\circ} \mathrm{C}$, B) $70^{\circ} \mathrm{C}$ and C) $100^{\circ} \mathrm{C}$ wed SPR band intensities. A red shift of the SPR band was observed because of the increase in the reaction temperature from $20^{\circ} \mathrm{C}$ to $70^{\circ} \mathrm{C}$. However, the increase from $80^{\circ} \mathrm{C}$ to $100^{\circ} \mathrm{C}$ resulted in a decrease in the wavelength of the absorbance peaks for the synthesized AgNPs with a small blue shift (Fig. 3). The peaks redshifted as the size of AgNPs increased. As shown in TEM images, these AgNPs were spherical with a mean diameter of $11.25,51.22$, and $34.75 \mathrm{~nm}$ when synthesized at $30^{\circ} \mathrm{C}, 70^{\circ} \mathrm{C}$, and $100^{\circ} \mathrm{C}$, respectively (Fig. 4).

\section{Effect of $\mathrm{AgNO}_{3}$ concentration on the synthesis of AgNPS}

The sizes of AgNPs can be controlled by varying the concentration of $\mathrm{AgNO}_{3}$ used for the reduction reaction. The synthesis of smaller AgNPs is accompanied by visible color changes of silver metal (Katok et al. 2009). A red shift of the SPR was observed because of the gradual increase in the concentration of $\mathrm{AgNO}_{3}$ (from 1 to $10 \mathrm{mM}$, Fig. 5). TEM images show spherical nanoparticles with a mean diameter of $14.11 \mathrm{~nm}$ at $1 \mathrm{mM} \mathrm{AgNO}_{3}$ concentration. However, anisotropy of irregular ellipsoids or rod-shaped AgNPs were formed at $4 \mathrm{mM} \mathrm{AgNO}_{3}$, with a mean length of $108 \mathrm{~nm}$ and width of $23.76 \mathrm{~nm}$ (Fig. 6).

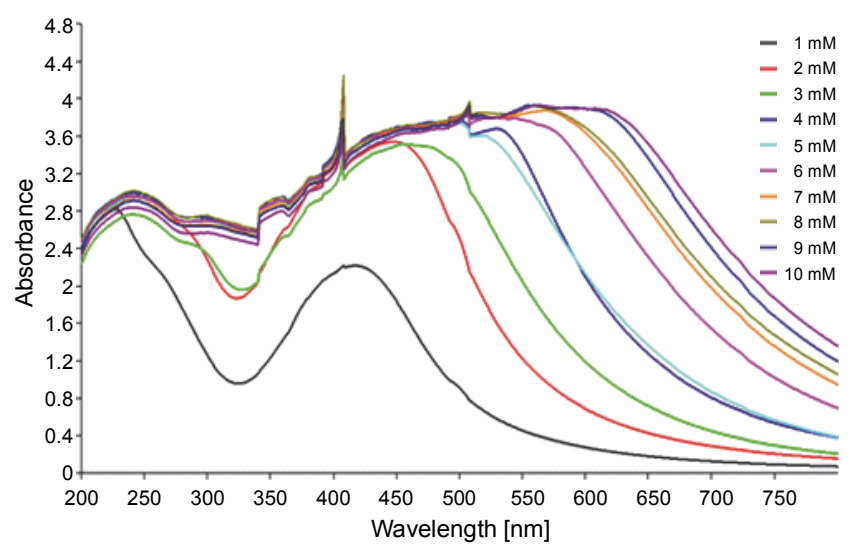

Fig. 5. UV-VIS spectra of AgNPs synthesized by prodigiosin at different $\mathrm{AgNO}_{3}$ concentration ranging from $1 \mathrm{mM}$ to $10 \mathrm{mM}$

\section{The effect of different concentrations of prodigiosin on the synthesis of AgNPS}

UV-VIS spectra of AgNPs synthesized using prodigiosin pigment at different concentrations are shown in Figure 7. SPR peak was not observed at $2 \mu \mathrm{g} / \mathrm{ml}$; however, the addition of $4 \mu \mathrm{g} / \mathrm{ml}$ enhanced the synthesis of AgNPs as indicated by SPR peaks. SPR peak intensities 

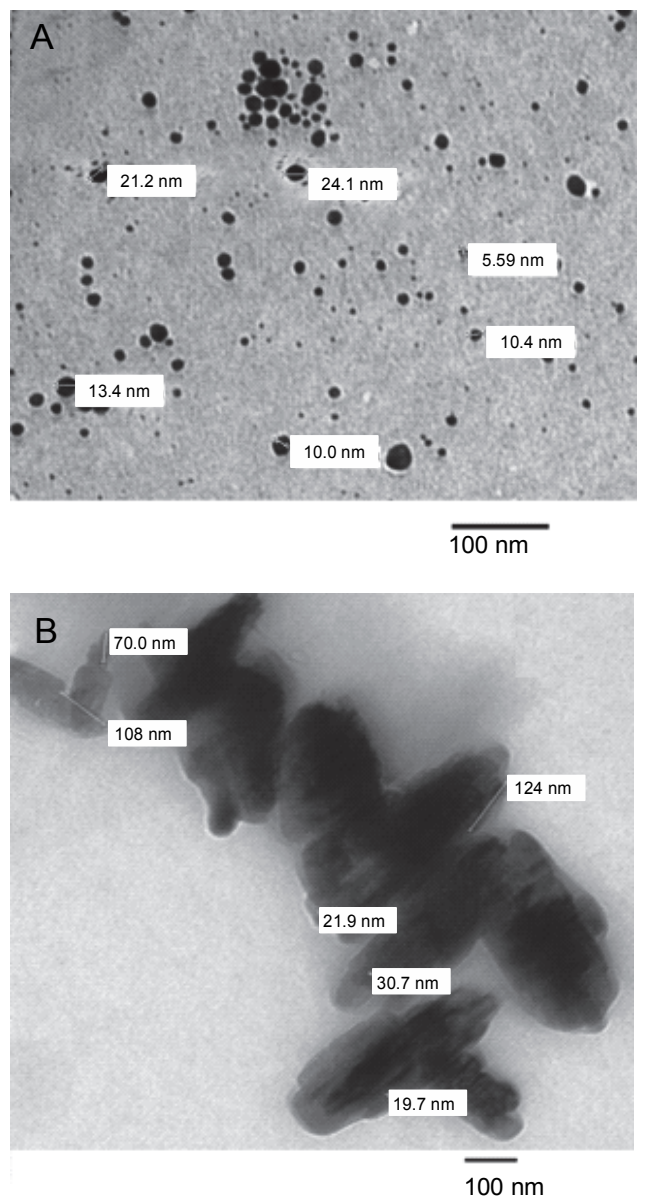

Fig. 6. TEM micrographs of AgNPs synthesized using $4 \mu \mathrm{g} / \mathrm{ml}$ prodigiosin at $\mathrm{pH} 13$ and two $\mathrm{AgNO}_{3}$ concentration A) $1 \mathrm{mM}$ and B) $4 \mathrm{mM}$

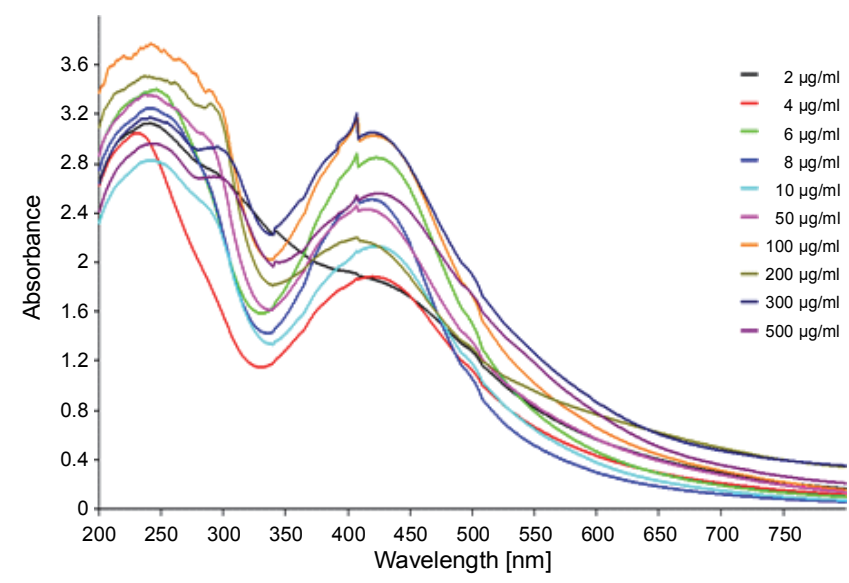

Fig. 7. UV-VIS spectra of AgNPs synthesized using different prodigiosin concentrations and $\mathrm{pH} 13$ at $30^{\circ} \mathrm{C}$ after $24 \mathrm{~h}$ and $1 \mathrm{mM} \mathrm{AgNO}{ }_{3}$ concentration

increased as the concentration of pigment increased. However, as the concentration increased from $4 \mu \mathrm{g} / \mathrm{ml}$ to $500 \mu \mathrm{g} / \mathrm{ml}$, the wavelength of absorbance peak for the synthesized AgNPs increased with a small red shift that
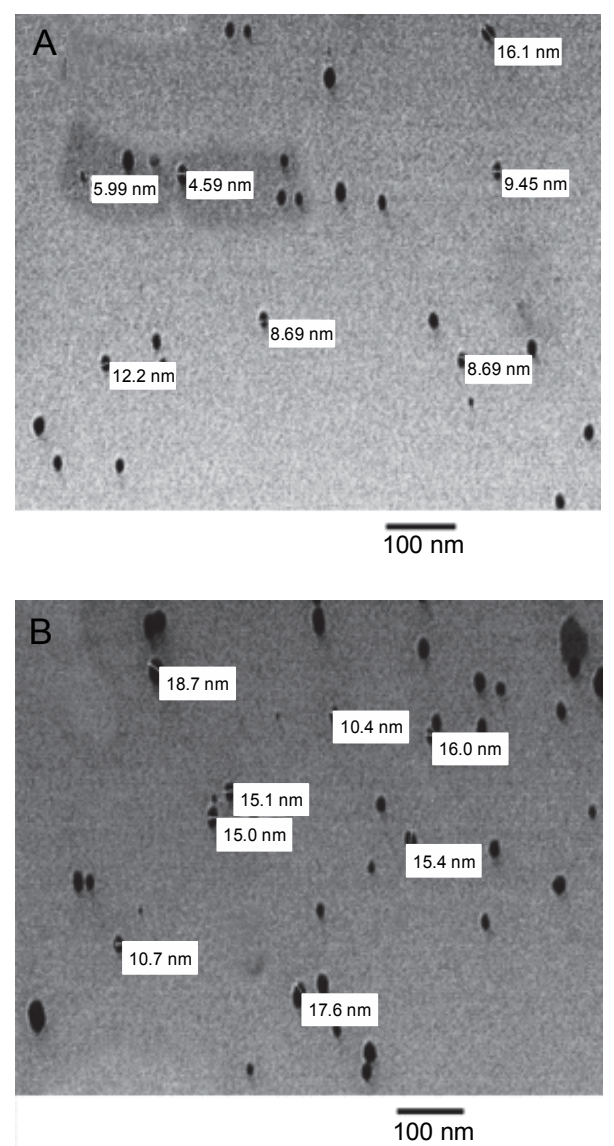

Fig. 8. TEM micrographs of AgNPs synthesized using $1 \mathrm{mM}$ $\mathrm{AgNO}_{3}$ at $\mathrm{pH} 13$ and A) $4 \mu \mathrm{g} / \mathrm{ml}$ and B) $500 \mu \mathrm{g} / \mathrm{ml}$ prodigiosin

appeared between 420 and $425 \mathrm{~nm}$. TEM images showed spherical nanoparticles with a mean diameter of $9.98 \mathrm{~nm}$ and $14.86 \mathrm{~nm}$ at $4 \mu \mathrm{g} / \mathrm{ml}$ and $500 \mu \mathrm{g} / \mathrm{ml}$, respectively (Fig. 8).

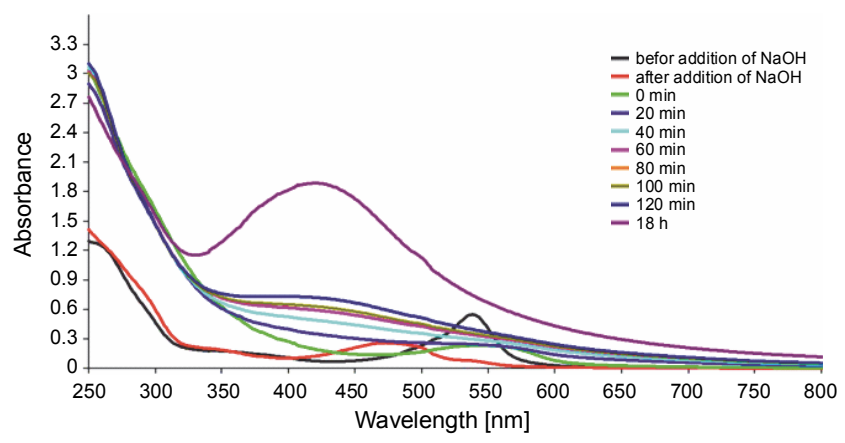

Fig. 9. UV-VIS spectra analysis of synthesized AgNPs after addition of $1 \mathrm{mM} \mathrm{AgNO}_{3}$ to $500 \mu \mathrm{g} / \mathrm{ml}$ prodigiosin pigment at $\mathrm{pH} 13$ during time intervals

\section{Time evolutions for synthesis of AgNPS}

Figure 9 showed no absorption peak after $20 \mathrm{~min}$, however, the absorption band intensity increased with 


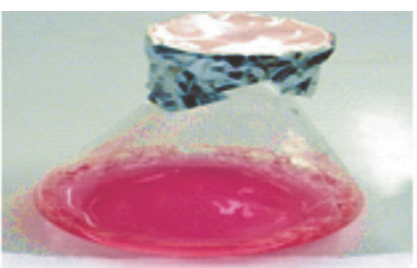

befor addition of $\mathrm{NaOH}$

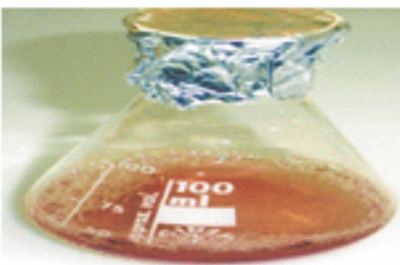

$20 \mathrm{~min}$

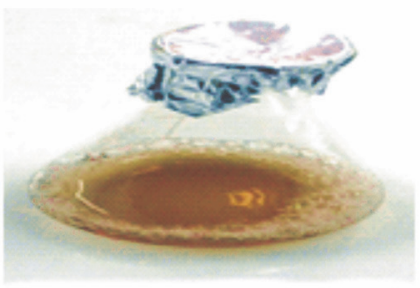

$80 \min$

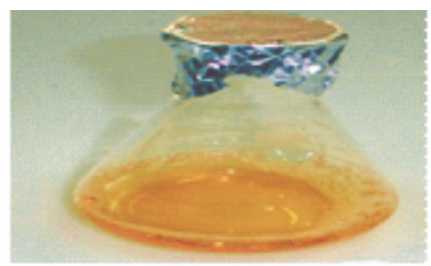

after addition of $\mathrm{NaOH}$

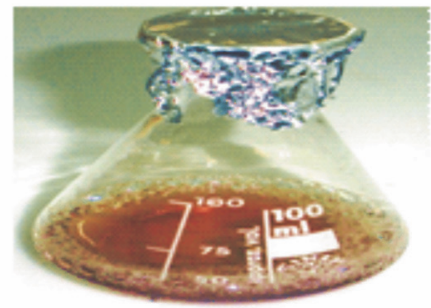

$40 \min$

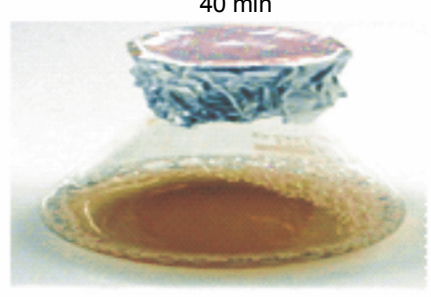

$100 \mathrm{~min}$

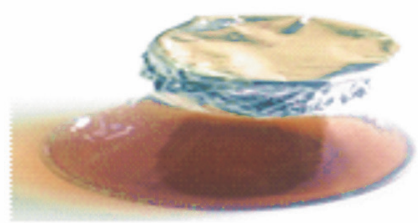

$18 \mathrm{~h}$

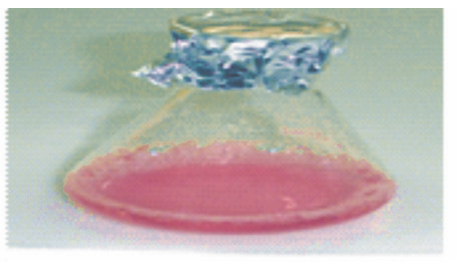

$0 \min$

after addition of $\mathrm{NaOH}$

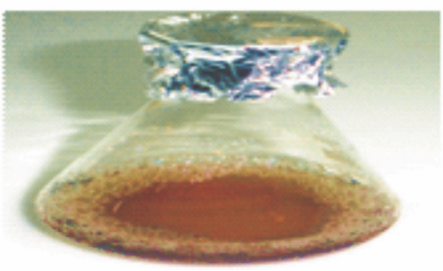

$60 \min$

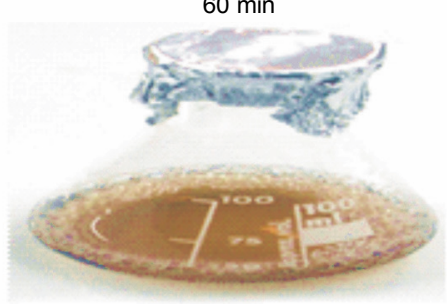

$120 \min$

Fig. 10. Formation of AgNPs using prodigiosin during time intervals

time duration due to the continuous formation of AgNPs. A weak absorption peak began to appear at $396 \mathrm{~nm}$ after $120 \mathrm{~min}$. An absorption peak of AgNPs at $422 \mathrm{~nm}$ after $18 \mathrm{~h}$ corresponds to those chemically conjugated with prodigiosin. Meanwhile, the color changed from red to yellow after addition of $\mathrm{NaOH}$ and returned to red after addition of $\mathrm{AgNO}_{3}$. Finally, the color changed to brown after $10 \mathrm{~min}$ as an indication of the formation of AgNPs (Fig. 10).

\section{$X$-ray diffraction pattern of AgNPs}

$\mathrm{XRD}$ measurements were performed to characterize crystal structures of the AgNPs as showed in Figure 11. Five well-defined characteristic diffraction peaks at $38.2^{\circ}, 44.1^{\circ}, 64.72^{\circ}, 77.4^{\circ}$, and $81.50^{\circ}$ ( $2 \theta$ values) corresponded to the reflections from the (111), (200), (220), (311), and (222) planes, respectively, and confirmed the crystalline phase of the AgNPs. Moreover, the intensity of the (111) diffraction was much stronger than those of the (200), (220), (311), and (222) diffractions.

\section{Reduction mechanism}

FTIR measurement was carried out to determine the reduction mechanism and identify potential functional groups responsible for the synthesis and stabilization of prodigiosin-conjugated AgNPs. Figure 12 shows the FTIR spectra of prodigiosin (before bioreduction) and prodigiosin-conjugated AgNPs (after bioreduction). Four bands (at $2815.2 \mathrm{~cm}^{-1}, 1654.0 \mathrm{~cm}^{-1}, 1438.0 \mathrm{~cm}^{-1}$, and $1423.0 \mathrm{~cm}^{-1}$ ) showed significant changes after synthesis of AgNPs. This peak, found only in AgNPs combination, may be due to conjugation of AgNPs with the free sites of methylene groups of prodigiosin pigment in symmetrical stretching at $2815.2 \mathrm{~cm}^{-1}$. Moreover, the peaks at $1654 \mathrm{~cm}^{-1}$ were found only in AgNPs combination due to 


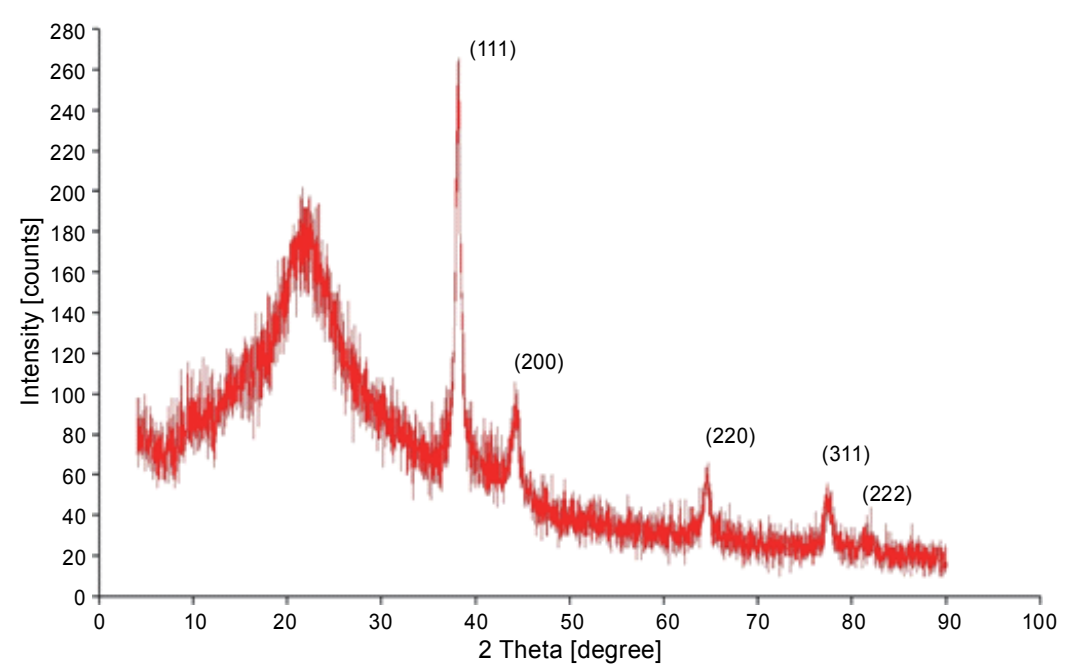

Fig. 11. The XRD pattern of Ag nanoparticles conjugated with prodigiosin, obtained using $\mathrm{CuK}$ radiation $(=0.154)$

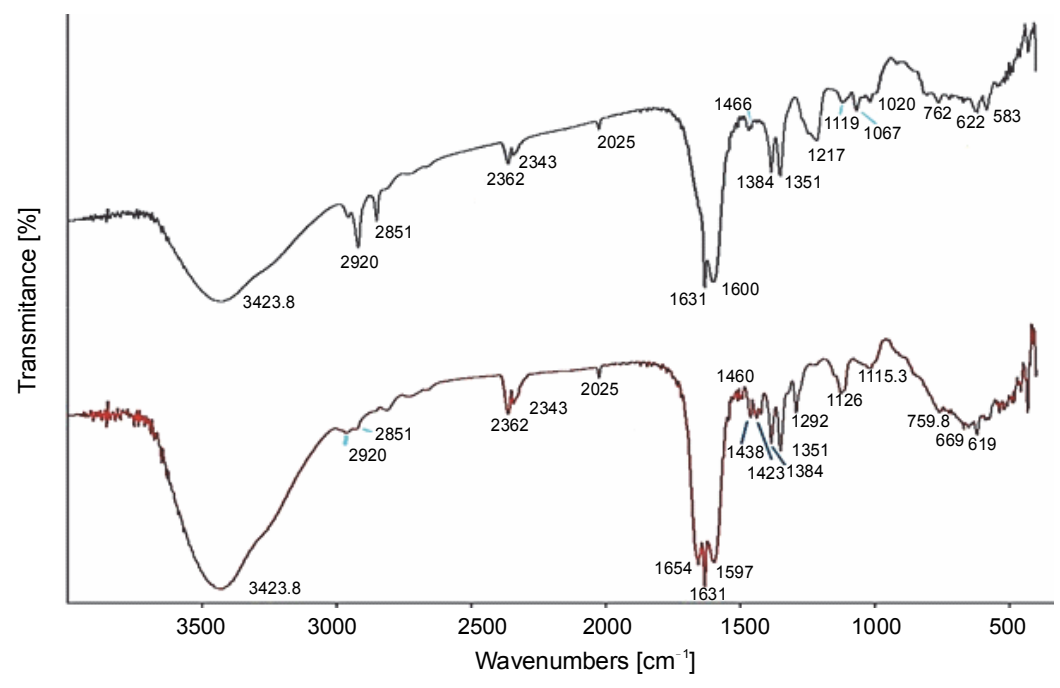

Fig. 12. FTIR spectra of prodigiosin (black line) and prodigiosin-conjugated nanosilver (PG-AgNPs) (red line)

the conjugation of AgNPs to the - $\mathrm{NH}$ function groups in prodigiosin. A new peak was also formed at both $1438.0 \mathrm{~cm}^{-1}$ and $1423 \mathrm{~cm}^{-1}$ due to the formation of new chemical covalent bonds between AgNPs and methyl groups present in prodigiosin, facilitating conjugation between nanometal and methyl groups in the dye.

The solubility of $\mathrm{AgNO}_{3}$ induce the formation of silver oxide in solutions of sufficient alkalinity and the presence of amphoteric properties is mainly a consequence of the equilibrium represented by the following reaction (Johnston et al., 1933).

$$
\mathrm{Ag}_{2} \mathrm{O}+2 \mathrm{OH}^{-}=2 \mathrm{AgO}^{-}+\mathrm{H}_{2} \mathrm{O}
$$

Figure 13 shows the amphoteric properties of silver oxide in alkaline solutions of the equilibrium reacting with positively charged pyrrole ring of prodigiosin which resulted in the formation of prodigiosin-conjugated AgNPs (PG-AgNPs). The predicted structure was generated using LigandScout 3.2 consisting of overall pharmacophore features: two hydrogen bond donors, two hydrogen bond acceptors, and an aromatic ring (Wolber and Langer, 2005). 

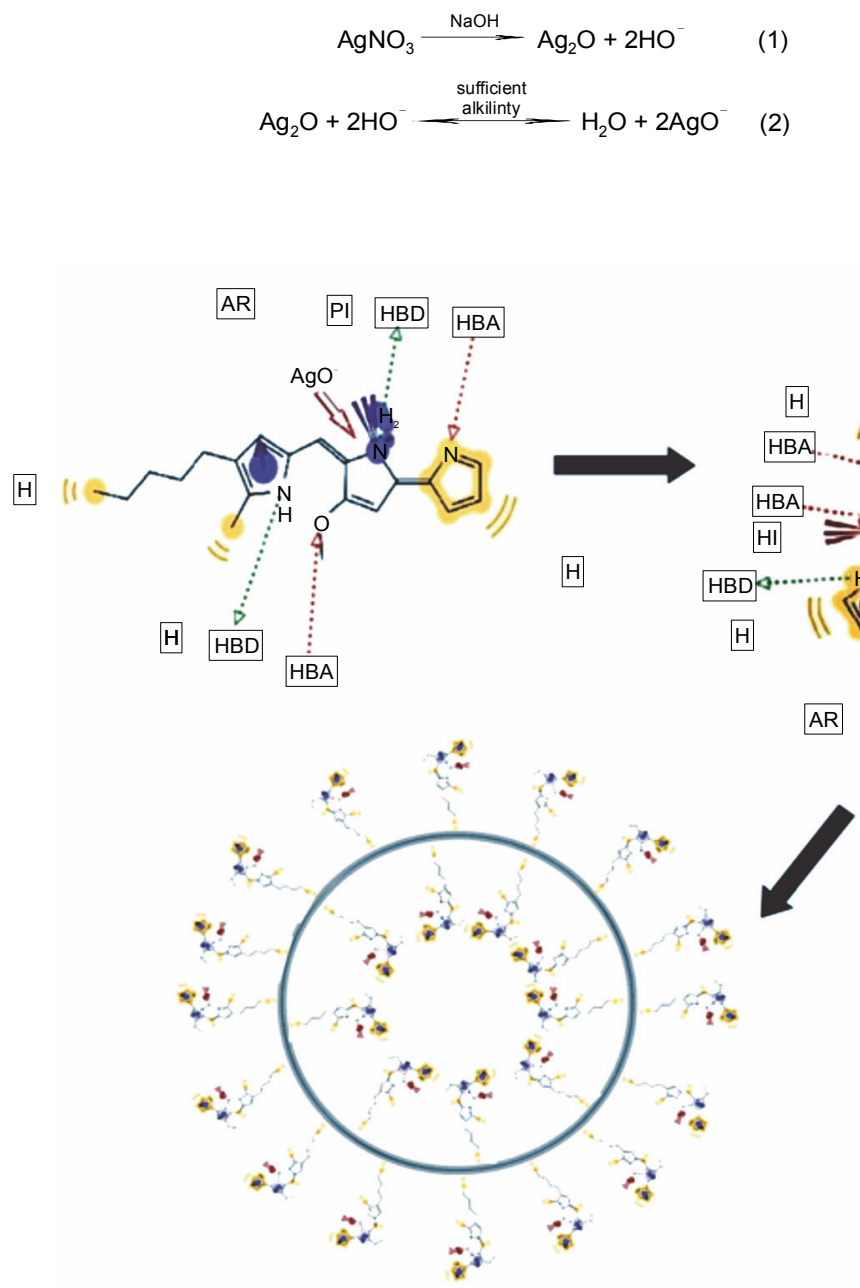

$\mathrm{H}$

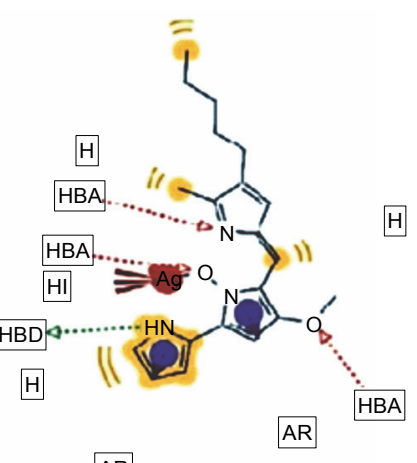

AR

Fig. 13. The mechanism of AgNPs synthesis using prodigiosin (chemical properties and ligand investigation of prodigiosin was performed using LigandScout 3.2)

\section{The cytotoxic effect of prodigiosin and prodigiosin-conjugated AgNPS}

PG-AgNPs had a potent anticancer activity against the liver cancer cell forms of HepG2 cell line $\left(\mathrm{IC}_{50}\right.$ $=29.8548 \mu \mathrm{g} / \mathrm{ml}$ ) compared to prodigiosin that had an $\mathrm{IC}_{50}$ of $44.834 \mu \mathrm{g} / \mathrm{ml}$ and a higher anticancer activity compared to DOX $\left(\mathrm{IC}_{50}=46.82 \mu \mathrm{g} / \mathrm{ml}\right)$. PG-AgNPs proved to be efficient, and as their anticancer efficacy increased with increasing concentration (Table 1).

\section{In silico study}

The in silico investigation for MEK1 kinase of the docked poses was performed on the basis of MolDock score followed by Rerank score and hydrogen bond interaction (H-bond) score. The best docking score for MEK1 kinase of the MolDock score was -162.59 with -130.103 Reranking score (Table 2). The binding affi- nity of selected inhibitors at the active site of human MEK1 kinase using MVD in decreasing order was PGAgNPs (-162.59), prodigiosin (-144.707), and DOX (-74.7941), respectively, based on MolDock and Rerank scores. Figure 14 shows the predicted active site in the human MEK1 kinase protein (4LMN) with the cavity marked with a green mesh. The best docking score to the receptor and the highest affinity of binding were recorded for PG-AgNPs $(-163.342)$ followed by prodigiosin (-145.714) and DOX (-87.6882) (Table 3). DOX, although having a low Rerank score, showed a good stability by the formation of four hydrogen bonds in the same cavity (Fig. 15). The prodigiosin docking hits showed common molecular interaction with Serine 212 (Ser 212). The ligand-protein interaction and the binding mode for top three docking hits are shown in Table 2 and Figure 15. 
Table 1. The cytotoxic effect of prodigiosin, prodigiosin-conjugated nanosilver (PG-AgNPs) and doxorubicin against HepG2 liver cancer cell lines

\begin{tabular}{|c|c|c|c|c|c|c|}
\hline \multirow[b]{2}{*}{$\begin{array}{l}\text { Concentration } \\
{[\mu \mathrm{g} / \text { well] }}\end{array}$} & \multicolumn{3}{|c|}{ Viability \% } & \multicolumn{3}{|c|}{$\mathrm{IC}_{50} \%$} \\
\hline & prodigiosin & $\begin{array}{l}\text { prodigiosin- } \\
\text {-conjugated } \\
\text { nanosilver }\end{array}$ & doxorubicin & prodigiosin & $\begin{array}{l}\text { prodigiosin- } \\
\text {-conjugated } \\
\text { nanosilver }\end{array}$ & doxorubicin \\
\hline 0 & 100 & 100 & 100 & \multirow{6}{*}{44.834} & \multirow{6}{*}{29.8548} & \multirow{6}{*}{46.82} \\
\hline 6.25 & 85.1080292 & 91.877986 & 66.4309639 & & & \\
\hline 12.5 & 74.0826708 & 80.465773 & 58.87607 & & & \\
\hline 25 & 66.1521499 & 72.1483975 & 54.8008932 & & & \\
\hline 50 & 35.2037757 & 30.5615196 & 48.7718645 & & & \\
\hline 100 & 30.1746649 & 25.9192634 & 45.8317827 & & & \\
\hline
\end{tabular}

Table 2. The comparative docking simulation results of selected prodigiosin-conjugated AgNPs, prodigiosin and doxorubicin with human MEK1 kinase including interacting residues and number of H-bonds, ligand from X-ray crystallized data of the protein data bank (4LMN.pdb) using MVD

\begin{tabular}{c|c|c|c|c|c|c|c}
\hline Ligand & $\begin{array}{c}\text { MolDock } \\
\text { score }\end{array}$ & $\begin{array}{c}\text { Rerank } \\
\text { score }\end{array}$ & HBond & MW & $\begin{array}{c}\text { Docking } \\
\text { score }\end{array}$ & $\begin{array}{c}\text { Interacting residues } \\
\text { of receptor human MEK1 } \\
\text { kinase }\end{array}$ & $\begin{array}{c}\text { Number } \\
\text { of H-bonds }\end{array}$ \\
\hline $\begin{array}{c}\text { Prodigiosin- } \\
\text {-conjugated } \\
\text { nanosilver }\end{array}$ & -162.59 & -130.103 & -3.81776 & 446.291 & -163.342 & Val211, Ser 212 & 2 \\
\hline Prodigiosin & -144.707 & -118.643 & 0 & 323.432 & -145.714 & Ser 212 & 1 \\
\hline Doxorubicin & -74.7941 & -71.7672 & -9.19366 & 534.448 & -87.6882 & $\begin{array}{c}\text { Lys 192, Ile 216, Met 219, } \\
\text { and Asn } 221\end{array}$ & 4 \\
\hline
\end{tabular}

\section{Discussion}

Nanoparticles have opened a new area in the field of cancer therapy because of their unique properties such as small size, controlled release of drugs, and reduced toxic side-effects. Prodigiosin pigment has antifungal, antibacterial, antiprotozoal, antimalarial, cytotoxic, and immunosuppressive activities (Samrot et al., 2011). The present study focused on the synthesis of AgNPs using prodigiosin produced by Serratia marcescens isolate WSE. Only a few research attempts focus on an in vivo setting to establish prodigiosin or prodigiosin derivatives-based antimicrobial agents, drug toxicity, and antitumor agents by using them in a combination with nanometals.

AgNPs exhibit a yellowish-brown color in aqueous solutions. Changes in the color of the reaction mixtures from red to brown are due to the excitation of SPR of AgNPs with its characteristic absorbance at $439 \mathrm{~nm}$ (Fig. 14) (Kreibig and Vollmer, 1995; Mulvaney, 1996;
Shankar et al., 2004; Xia and Halas, 2011; Muthukrishnan and Nanda, 2013). The absorption peak assigned to the SPR band of AgNPs, can be attributed to the collective oscillation of the conduction electrons of metallic nanostructures induced by the incident light field (Guo et al., 2014). The intensity and width of the SPR depend on size, shape, morphology, spatial orientation, optical constants of the particles and the surrounding environment (Mulvaney, 1996; Knoll and Keilmann, 1999; Huang and $\mathrm{Xu}, 2010$ ).

The alkaline $\mathrm{pH}$ plays an important role in the synthesis of smaller size AgNPs, where a broad peak related to AgNPs synthesis starts appearing at $\mathrm{pH}$ 9. The intensity of the band increased as the $\mathrm{pH}$ value increased, and as the size of AgNPs formed reduced. In addition, due to an increase in the $\mathrm{Ag}^{+}$ion reduction rate, the AgNPs synthesis rate increased with increasing $\mathrm{pH}$ (Abdel-Mohsen et al., 2014). The alkaline conditions accelerated $\mathrm{AgNO}_{3}$ reduction rate. However, at acidic or 
neutral $\mathrm{pH}$ no reduction was observed. Under the alkaline conditions, the absorption peak of AgNPs showed high intensity and blue shift as an indication that the concentration of AgNPs increased and the size was reduced, respectively. As the $\mathrm{pH}$ value reduced, the surface plasmon band of the AgNPs red-shifted toward longer wavelengths which indicated that the size of AgNPs

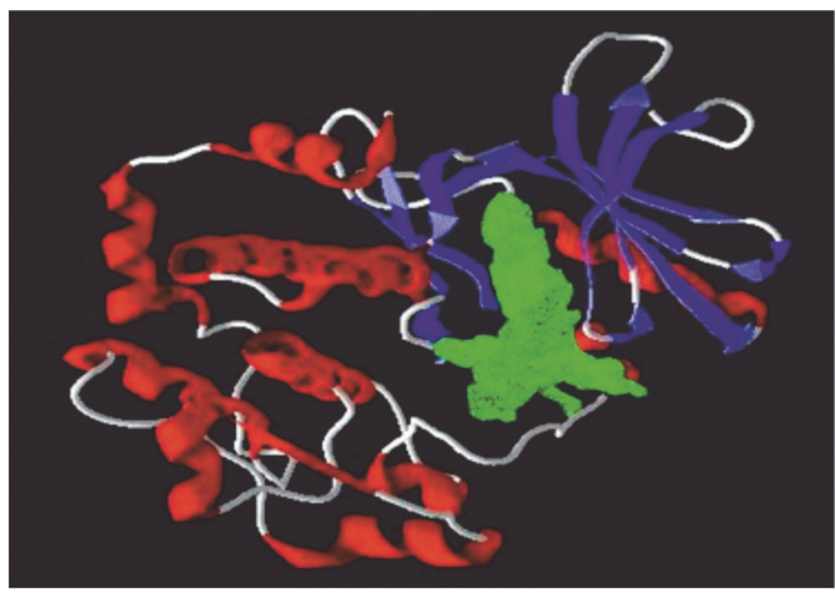

Fig. 14. Human MEK1 kinase protein (4LMN) showing the cavity (green mesh) at the active site

could be controlled by varying the $\mathrm{pH}$ from 9 to 13 (Kerker, 1985; Sönnichsen et al., 2002; Ganesh Babu and Gunasekaran, 2009; Abdel-Mohsen et al., 2014). The temperature of the synthesis reaction of AgNPs influences AgNPs growth, shape, and size. The results of our experiments suggest that silver ion reduction strongly depended on the reaction temperature, i.e., at higher reaction temperatures the reduction rate of silver ions $\left(\mathrm{Ag}^{+}\right)$to $\mathrm{AgNPs}\left(\mathrm{Ag}^{0}\right)$ increased (Abdel-Mohsen et al., 2014). Lower reaction temperatures usually resulted in formation of AgNPs with a narrower size distribution. The control of uniform shape is a very important step for the efficient utilization of temperature in the synthesis of AgNPs using prodigiosin. It is well known that an absorption band appears at $419-475 \mathrm{~nm}$ in a $10-100^{\circ} \mathrm{C}$ temperature range and is related to SPR of AgNPs (Aslan et al., 2005; Abdel-Mohsen et al., 2012; Hyllested et al., 2015). When the temperature was increased to $30^{\circ} \mathrm{C}$, the mean size of AgNPs increased to $11.25 \mathrm{~nm}$. A further increase in the temperature (to $70^{\circ} \mathrm{C}$ ) resulted in well-dispersed, uniform sized AgNPs of about $51.22 \mathrm{~nm}$; however, an increase to $100^{\circ} \mathrm{C}$ resulted in the formation of smaller, uniformly sized AgNPs of about $34.75 \mathrm{~nm}$.
It is easily understandable that $\mathrm{AgNO}_{3}$ concentration plays a role in size and shape of formed nanoparticles. It has been shown that due to its role in increasing the reduction rate the peak intensity increased as the $\mathrm{AgNO}_{3}$ concentration increased from 1 to $10 \mathrm{mM}$ (Dubey et al., 2010; Zaki et al., 2012; Maria et al., 2014). The SPR band red-shifted with the increasing concentration of $\mathrm{AgNO}_{3}$ from $1 \mathrm{mM}$ to $10 \mathrm{mM}$ indicating an increase in the size of AgNPs. It can therefore be assumed that the maximum absorbance peak will red-shift to longer wavelengths when the particle size increases (Heard et al., 1983; Abdel-Mohsen et al., 2014). This result showed that the increase in silver ion concentration induced the growth of AgNPs and resulted in increased particle size (Jiang et al., 2008). The appearance of a peak at $417 \mathrm{~nm}$ in a SPR indicated the formation of AgNPs (Wang et al., 2004). The maximum absorbance peak intensity increased gradually with the increase in the $\mathrm{AgNO}_{3}$ concentration until $3 \mathrm{mM} \mathrm{AgNO}$. At a concentration of $4 \mathrm{mM}$ $\mathrm{AgNO}_{3}$ another phenomenon, formation of anisotropic rod-shaped AgNPs, was observed that were confirmed using TEM and DLS (Annadhasan et al., 2014). The shape of AgNPs changed from spherical to anisotropic nano-rod structures, when $\mathrm{AgNO}_{3}$ concentration increased to $4 \mathrm{mM}$ and at prodigiosin concentration of $4 \mu \mathrm{g} / \mathrm{ml}$. The formation of nanoparticles could be observed when prodigiosin concentration was within a suitable range for nucleation. The results indicated that using $4 \mu \mathrm{g} / \mathrm{ml}$ prodigiosin was sufficient for the synthesis of well-defined AgNPs. No AgNPs were observed below that concentration. The characteristic SPR band of the solution was observed between $420-425 \mathrm{~nm}$ at a concentration of prodigiosin higher than $2 \mu \mathrm{g} / \mathrm{ml}$, which could be due to the formation of spherical-shaped AgNPs (Annadhasan et al., 2014). It is well known that a surface plasmon band of spherical AgNPs appears around $420 \mathrm{~nm}$ (Park et al., 2003; Suber et al., 2005; Chang et al., 2014). The particle size obtained from DLS measurement was larger than TEM result (9.98 $\mathrm{nm}$ ), because DLS measures the hydrodynamic radius that considers the prodigiosin pigment on the surface of AgNPs (El-Batal et al., 2014). Spherical-shaped nanoparticles with a mean diameter of $14.86 \mathrm{~nm}$ were obtained at $\mathrm{pH} 13$ after $18 \mathrm{~h}$ of reaction with $500 \mu \mathrm{g} / \mathrm{ml}$ prodigiosin at $1 \mathrm{mM}$ of $\mathrm{AgNO}_{3}$ (Sönnichsen et al., 2002). The synthesis of AgNPs using prodigiosin was also confirmed by characteristic peaks observed by XRD. The major peaks at $2 \theta$ of about $38.1^{\circ}, 44.3^{\circ}$, 

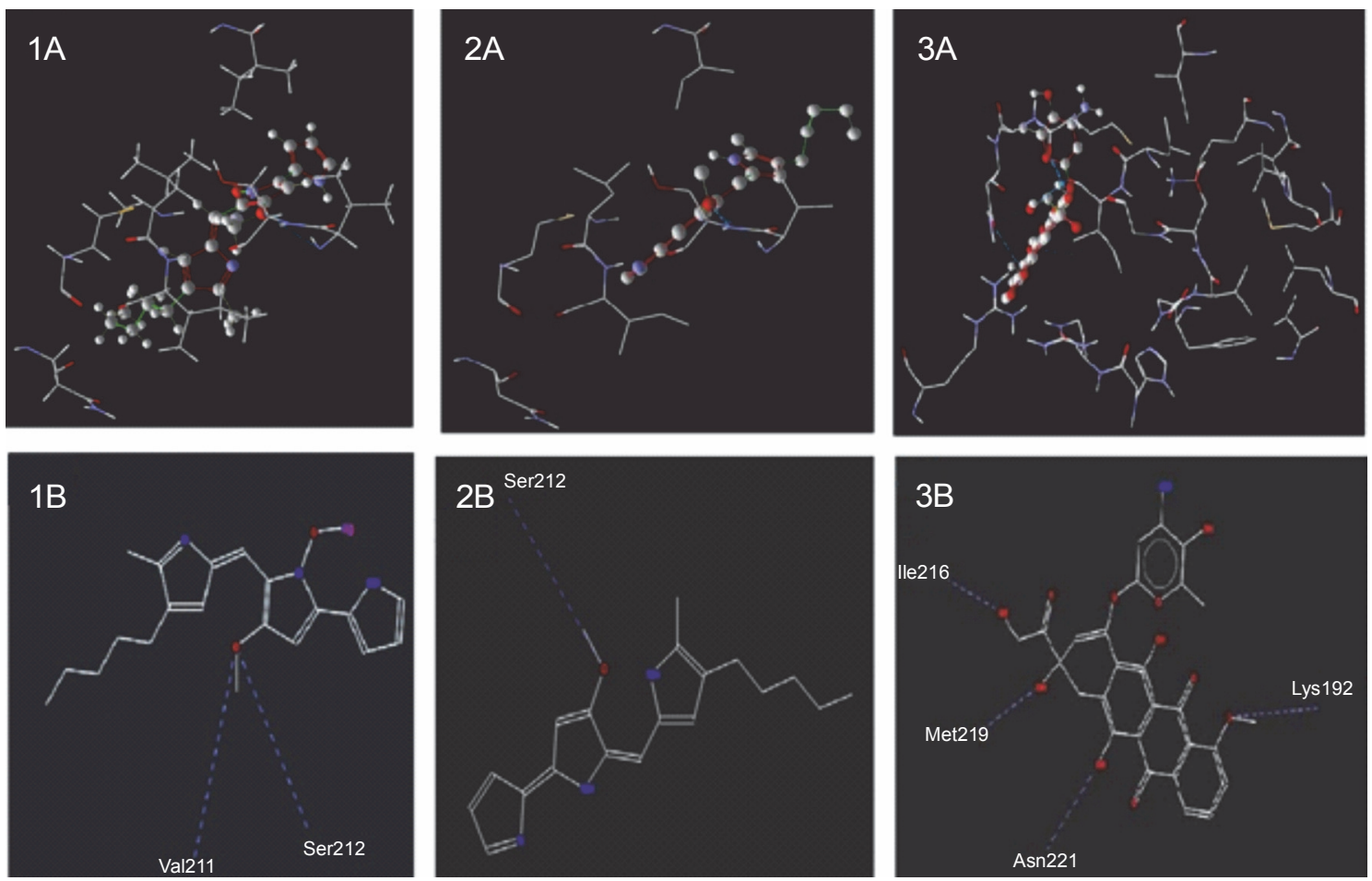

Fig. 15. Comparison of the docking interaction: $1 \mathrm{~A}$ and $1 \mathrm{~B}$ - for prodigiosin-conjugated nanosilver, $2 \mathrm{~A}$ and $2 \mathrm{~B}$ - for prodigiosin, and $3 \mathrm{~A}$ and $3 \mathrm{~B}$-for doxorubicin with human MEK1 kinase (4LMN)

$64.5^{\circ}, 77.5^{\circ}$, and $81.5^{\circ}$ of AgNPs were assigned to the (111), (200), (220), (311), and (222) crystallographic planes [JCPDS card No. 01-1167] for silver nanocrystals, respectively (Hanawalt et al., 1938; Das et al., 2011). The highly intense diffraction peak observed at $38.1^{\circ}$ confirmed a formation of pure crystalline AgNPs (Das et al., 2011; El Baz et al., 2015). The reduction and stabilization mechanisms involved in the synthesis of AgNPs were investigated using FTIR. The efficient conjugation of prodigiosin to form AgNPs and possible functional groups of capping agents were achieved through the chemical reaction of negatively charged silver oxide $\left(\mathrm{AgO}^{-}\right)$and positively charged nitrogen atom of pyrrole ring. The reaction resulted in the formation of prodigiosin silver oxide, as confirmed by FTIR spectra. The FTIR spectra revealed that four bands between $400-4000 \mathrm{~cm}^{-1}$ wavenumbers (at $2815.2 \mathrm{~cm}^{-1}, 1654.0 \mathrm{~cm}^{-1}, 1438.0 \mathrm{~cm}^{-1}$, and $1423.0 \mathrm{~cm}^{-1}$ ) showed significant changes after the reduction of silver ions and formation of PG-AgNPs.

Some members of prodigiosin family have great potential of inducing apoptosis in various human hematopoietic cancer cells, colon cancer cells, B-cell, and chronic lymphocytic leukemia cells. Interestingly, prodigiosin does not have any marked toxicity in nonmalignant cell lines (Campàs et al., 2003; Kavitha et al., 2010). Apoptosis in liver cancer (HepG2) cells and cytotoxic mechanism induced by functionalized gold nanoparticles were studied and evaluated using 3-(4,5-dimethylthiazol-2-yl)2,5-diphenyltetrazolium bromide MTT (-(4,5-dimethylthiazol-2-yl)-2,5-diphenyltetrazolium bromide) assay and sulforodamine B (SRB) assay, Annexin-V/PI double-staining assay, cell cycle as reported by Ashokkumar and coworkers (2014).

DOX is one of the most widely used chemotherapeutics for the treatment of hepatocellular cancer. It is also an anticancer drug that induces apoptosis and chemosensitivity in hepatoma cell lines, human hepatocellular cancer cell lines (HepG2), which were targeted with DOX and MEK enzyme inhibitors, alone or in combination (Friedman, 1983; Chlebowski et al., 1984; Lai et al., 1988; Lin et al., 1997; Yang et al., 2000; Lee et al., 2002; Xu et al., 2011). HepG2 cell line is widely used for in vitro studies. It mostly expresses drug-metabolizing enzymes, and is also widely used as a cellular experimental model in pharmaceutical studies for the production of new drugs and to gain insights into drug metabolism, including enzymes drug's inhibition or induction potential (Knasmüller et al., 1998; Castell et al., 2006; Qiu et al., 2015). 
Hassankhani and coworkers (2015) reported that prodigiosin may have a great potential for colorectal cancer-directed therapy as it induced apoptosis in HT-29 cells (Hassankhani et al., 2015). The toxicity potential of prodigiosin and PG-AgNPs on liver cancer cells was examined using the HepG2 cell line. The cells were exposed to various concentrations of prodigiosin and PG-AgNPs for $24 \mathrm{~h}$ and $48 \mathrm{~h}$, and the toxicity effects were assessed after that period. The results showed that PG-AgNPs decreased cell viability in a time-dependent manner. In the present study, the effects of DOX, PG-AgNPs, and prodigiosin, on liver cancer cells, both in vitro and in silico, were examined. The cytotoxicity assessment is essential to any study of therapeutic potential of various compounds, particularly when assessing their applicability as an anticancer drug. The inhibitory concentration $\left(\mathrm{IC}_{50}\right.$ value) for PG-AgNPs was determined to be $29.8548 \mu \mathrm{g} / \mathrm{ml}$, however, the inhibitory concentration of prodigiosin $\left(\mathrm{IC}_{50}\right.$ value) was $44.834 \mu \mathrm{g} / \mathrm{ml}$. The lower the value of the half maximal inhibitory concentration $\left(\mathrm{IC}_{50}\right)$ of a drug, the higher is the sensitivity to the drug treatment. MEK inhibition may hold promise for the treatment of hepatocellular cancer and potential for treatment of some cancers (Wang et al., 2007; Choi et al., 2008; Hatzivassiliou et al., 2013). Choi and coworkers (2008) analyzed DOX combined with mitogen-activated protein kinase-extracellular signal-regulated kinase (MEKERK)-targeted therapy and suggested that the treatment begins from the time of DOX addition which may provide enhanced anticancer effects (Choi et al., 2008). The in silico study showed a higher affinity between PG-AgNPs and human MEK1 kinase than with prodigiosin and DOX, which was confirmed by the Rerank score. The interaction was analyzed by the formation of the hydrogen bond with human MEK1 kinase, where it was observed that PG-AgNPs formed two hydrogen bonds with Val211 and Ser 212 in the active site cavity. The hydrogen bonds between prodigiosin and Ser 212 were formed with human MEK1 kinase active site. Interestingly, four hydrogen bonds were formed between DOX and Lys 192, Ile 216, Met 219, and Asn 221.

\section{Conclusions}

Different shapes and sizes of nanoparticles can be synthesized by controlling the reaction conditions. Prodigiosin pigment has a promising role in stabilization and synthesis of AgNPs as a reducing and capping agent.
In the present in vitro and in silico analyzes a high therapeutic potential of PG-AgNPs against human liver cancer and MEK1 kinase inhibition is shown. The present investigation demonstrated the potential of prodigiosin conjugated with AgNPs for apoptosis studies in liver cancer cells.

\section{Acknowledgments}

The authors would like to thank the Nanotechnology Research Unit (P.I. Prof. Dr. Ahmed Ibrahim El-Batal), Drug Microbiology Lab, Drug Radiation Research Department, NCRRT, Cairo, Egypt, for financing and supporting this study under the project Nutraceuticals and Functional Foods Production by using Nano/Biotechnological and Irradiation Processes.

\section{Author contribution}

All authors conceived the study, wrote the manuscript, designed and performed the experiments, analyzed and interpreted data, supervised the research, and interpreted data. Also, all authors read, revised, and approved the final manuscript.

\section{Compliance with ethical standards Conflict of interest}

The authors declare that they have no conflict of interest.

\section{Ethical statement}

This article does not contain any studies with human participants or animals performed by any of the authors.

\section{References}

Abdel-Mohsen A.M., Abdel-Rahman R.M., Fouda M.M.G., Vojtova L., Uhrova L., Hassan A.F., Al-Deyab S.S., ElShamy I.E., Jancar J. (2014) Preparation, characterization and cytotoxicity of schizophyllan/silver nanoparticle composite. Carbohydr. Polym. 102: 238-245.

Abdel-Mohsen A.M., Abdel-Rahman R.M., Hrdina R., Imramovský A., Burgert L., Aly A.S. (2012) Antibacterial cotton fabrics treated with core-shell nanoparticles. Int. J. Biol. Macromol. 50: 1245-1253.

Adelere I.A., Lateef A. (2016) A novel approach to the green synthesis of metallic nanoparticles: the use of agro-wastes, enzymes, and pigments. Nanotechnol. Rev. 5: 567587.

Allen G.R., Reichelt J.L., Gray P.P. (1983) Influence of environmental factors and medium composition on Vibrio gazogenes growth and prodigiosin production. Appl. Environ. Microbiol. 45: 1727-1732.

Anderson R.J., Bendell D.J., Groundwater P.W. (2004) Organic spectroscopic analysis. Royal Society of Chemistry, Cambridge.

Annadhasan M., Muthukumarasamyvel T., Sankar Babu V.R., Rajendiran N. (2014) Green synthesized silver and gold nanoparticles for colorimetric detection of $\mathrm{Hg} 2+, \mathrm{Pb2}$, and $\mathrm{Mn} 2+$ in aqueous medium. ACS Sustain Chem. Eng. 2: 887-896. 
Apte M., Sambre D., Gaikawad S., Joshi S., Bankar A., Kumar A., Zinjarde S. (2013) Psychrotrophic yeast Yarrowia lipolytica NCYC 789 mediates the synthesis of antimicrobial silver nanoparticles via cell-associated melanin. AMB Express 3: 32.

Ashokkumar T., Prabhu D., Geetha R., Govindaraju K., Manikandan R., Arulvasu C., Singaravelu G. (2014) Apoptosis in liver cancer (HepG2) cells induced by functionalized gold nanoparticles. Colloid. Surface. B 123: 549-556.

Aslan K., Lakowicz J.R., Geddes C.D. (2005) Rapid deposition of triangular silver nanoplates on planar surfaces: application to metal-enhanced fluorescence. J. Phys. Chem. B 109: 6247-6251.

Azeez M.A., Lateef A., Asafa T.B., Yekeen T.A., Akinboro A., Oladipo I.C., Gueguim-Kana E.B., Beukes L.S. (2017) Biomedical applications of cocoa bean extract-mediated silver nanoparticles as antimicrobial, larvicidal and anticoagulant agents. J. Clust. Sci. 28: 149-164.

Bhattacharya D., Gupta R.K. (2005) Nanotechnology and potential of microorganisms. Crit. Rev. Biotechnol. 25: 199-204.

Boger D.L., Patel M. (1988) Total synthesis of prodigiosin, prodigiosene, and desmethoxyprodigiosin: Diels-Alder reactions of heterocyclic azadienes and development of an effective palladium (II)-promoted 2, 2'-bipyrrole coupling procedure. J. Org. Chem. 53: 1405-1415.

Bunting M.I. (1940) A description of some color variants produced by Serratia marcescens, strain 274. J. Bacteriol. 40: 57.

Campàs C., Dalmau M., Montaner B., Barragán M., Bellosillo B., Colomer D., Pons G., Pérez-Tomás R., Gil J. (2003) Prodigiosin induces apoptosis of $B$ and $T$ cells from B-cell chronic lymphocytic leukemia. Leukemia 17: 746-750.

Castell J.V., Jover R., Martínez-Jiménez C.P., Gómez-Lechón M.J. (2006) Hepatocyte cell lines: their use, scope and limitations in drug metabolism studies. Expert Opin. Drug Metab. Toxicol. 2: 183-212.

Castro A.J., Corwin A.H., Waxham F.J., Beilby A.L. (1959) Products from Serratia marcescens1, 2. J. Org. Chem. 24: 455-459.

Casullo de Araújo H.W., Fukushima K., Takaki G.M.C. (2010) Prodigiosin production by Serratia marcescens UCP 1549 using renewable-resources as a low cost substrate. Molecules 15: 6931-6940.

Cerdeño A.M., Bibb M.J., Challis G.L. (2001) Analysis of the prodiginine biosynthesis gene cluster of Streptomyces coelicolor A3(2): New mechanisms for chain initiation and termination in modular multienzymes. Chem. Biol. 8: 817829.

Chang T.M., Sinharay S., Astashkin A.V., Tomat E. (2014) Prodigiosin analogue designed for metal coordination: stable zinc and copper pyrrolyldipyrrins. Inorg. Chem. 53: 7518-7526.

Chen D., Han Y., Gu Z. (2006) Application of statistical methodology to the optimization of fermentative medium for carotenoids production by Rhodobacter sphaeroides. Process Biochem. 41: 1773-1778.
Chlebowski R.T., Brzechwa-Adjukiewicz A., Cowden A., Block J.B., Tong M., Chan K.K. (1984) Doxorubicin (75 mg/m2) for hepatocellular carcinoma: clinical and pharmacokinetic results. Cancer Treat. Rep. 68: 487-491.

Choi J., Yip-Schneider M., Albertin F., Wiesenauer C., Wang Y., Schmidt C.M. (2008) The Effect of Doxorubicin on MEK-ERK Signaling Predicts Its Efficacy in HCC. J. Surg. Res. 150: 219-226.

D’Aoust J.Y., Gerber N.N. (1974) Isolation and purification of prodigiosin from Vibrio psychroerythrus. J. Bacteriol. 118: 756-757.

Da Silva Melo P., Durán N., Haun M. (2000) Cytotoxicity of prodigiosin and benznidazole on V79 cells. Toxicol. Lett. 116: 237-242.

Das M.R., Sarma R.K., Saikia R., Kale V.S., Shelke M.V., Sengupta P. (2011) Synthesis of silver nanoparticles in an aqueous suspension of graphene oxide sheets and its antimicrobial activity. Colloid. Surface. B 83: 16-22.

Díaz-Ruiz C., Montaner B., Pérez-Tomás R. (2001) Prodigiosin induces cell death and morphological changes indicative of apoptosis in gastric cancer cell line HGT-1. Histol. Histopathol. 16: 415-421.

Duane M.M., Robert C., Reynolds J. (1997) X-ray diffraction and the identification and analysis of clay minerals, 2ed edn. Oxford Press, London.

Dubey S.P., Lahtinen M., Sillanpää M. (2010) Green synthesis and characterizations of silver and gold nanoparticles using leaf extract of Rosa rugosa. Colloid. Surface. A 364: 34-41.

Durán N., Marcato P.D., De Souza G.I.H., Alves O.L., Esposito E. (2007) Antibacterial effect of silver nanoparticles produced by fungal process on textile fabrics and their effluent treatment. J. Biomed. Nanotechnol. 3: 203-208.

El-Batal A.I., Amin M.A., Shehata M.M.K., Hallol M.M.A. (2013) Synthesis of silver nanoparticles by Bacillus stearothermophilus using gamma radiation and their antimicrobial activity. World Appl. Sci. J. 22: 1-16.

El-Batal A.I., Haroun B.M., Farrag A.A., Baraka A., El-Sayyad G.S. (2014) Synthesis of silver nanoparticles and incorporation with certain antibiotic using gamma irradiation. Br. J. Pharm. Res. 4: 1341.

El Baz A.F., El Batal A.I., Abomosalam F.M., Tayel A.A., Shetaia Y.M., Yang S. (2015) Extracellular biosynthesis of anti Candida silver nanoparticles using Monascus purpureus. J. Basic Microbiol. 56: 531-540.

Faraag A.H., El-Batal A.I., El-Hendawy H.H. (2017) Characterization of prodigiosin produced by Serratia marcescens strain isolated from irrigation water in Egypt. Nat. Sci. 15: $55-68$.

Fayaz A.M., Balaji K., Girilal M., Yadav R., Kalaichelvan P.T., Venketesan R. (2010) Biogenic synthesis of silver nanoparticles and their synergistic effect with antibiotics: a study against gram-positive and gram-negative bacteria. Nanomedicine 6(1): 103-109.

Friedman M.A. (1983) Primary hepatocellular cancer-present results and future prospects. Int. J. Radiat. Oncol. Biol. Phys. 9: 1841-1850. 
Fullan N.P., Lynch D.L., Ostrow D.H. (1977) Effects of bacterial extracts on Chinese-Hamster cells and Rat Neoplasms. Microbios. Lett. 5: 157-161.

Gade A.K., Bonde P., Ingle A.P., Marcato P.D., Durán N., Rai M.K. (2008) Exploitation of Aspergillus niger for synthesis of silver nanoparticles. J. Biobased Mater. Bioenergy. 2: 5.

Ganesh Babu M.M., Gunasekaran P. (2009) Production and structural characterization of crystalline silver nanoparticles from Bacillus cereus isolate. Colloid. Surface. B 74: 191-195.

Ganesh Babu M.M., Gunasekaran P. (2013) Extracellular synthesis of crystalline silver nanoparticles and its characterization. Mater Lett. 90: 162-164.

Garg R., Namazkar S., Ahmad W.Z., Nordin N. (2013) Production and characterization of crude and encapsulated prodigiosin pigment. Int. J. Chem. Sci. Appl. 4: 116-129.

Gargallo-Viola D. (1989) Enzyme polymorphism, prodigiosin production, and plasmid fingerprints in clinical and natu rally occurring isolates of Serratia marcescens. J. Clin. Microbiol. 27: 860-868.

Gerber N.N. (1975) Prodigiosin-like pigments. CRC Crit. Rev. Microbiol. 3: 469-485.

Gerber N.N., Gauthier M.J. (1979) New prodigiosin-like pigment from Alteromonas rubra. Appl. Environ. Microbiol. 37: 1176-1179.

Gerber N.N., Stahly D.P. (1975) Prodiginine (prodigiosin-like) pigments from Streptoverticillium rubrireticuli, an organism that causes pink staining of polyvinyl chloride. Appl. Microbiol. 30: 807-810.

Gong P., Li H., He X., Wang K., Hu J., Tan W., Zhang S., Yang X. (2007) Preparation and antibacterial activity of $\mathrm{Fe}_{3} \mathrm{O}_{4} @$ Ag nanoparticles. Nanotechnology 18: 285604.

Guo Q., Guo Q., Yuan J., Zeng J. (2014) Biosynthesis of gold nanoparticles using a kind of flavonol: dihydromyricetin. Colloid. Surface. A 441: 127-132.

Gurunathan S., Kalishwaralal K., Vaidyanathan R., Venkataraman D., Pandian S.R.K., Muniyandi J., Hariharan N., Eom S.H. (2009a) Biosynthesis, purification and characterization of silver nanoparticles using Escherichia coli. Colloid. Surface. B 74: 328-335.

Gurunathan S., Lee K.J., Kalishwaralal K., Sheikpranbabu S., Vaidyanathan R., Eom S.H. (2009b) Antiangiogenic properties of silver nanoparticles. Biomaterials 30: 6341-6350.

Hanawalt J.D., Rinn H.W., Frevel L.K. (1938) Chemical analysis by X-ray diffraction. Ind. Eng. Chem. Anal. Ed. 10: 457-512.

Hannun Y.A. (1997) Apoptosis and the dilemma of cancer chemotherapy. Blood 89: 1845-1853.

Harris A.K.P., Williamson N.R., Slater H., Cox A., Abbasi S., Foulds I., Simonsen H.T., Leeper F.J., Salmond G.P.C. (2004) The Serratia gene cluster encoding biosynthesis of the red antibiotic, prodigiosin, shows species- and straindependent genome context variation. Microbiology 150: 3547-3560.

Hassankhani R., Sam M.R., Esmaeilou M., Ahangar P. (2015) Prodigiosin isolated from cell wall of Serratia marcescens alters expression of apoptosis-related genes and increases apoptosis in colorectal cancer cells. Med. Oncol. 32: 1-8.

Hatzivassiliou G., Haling J.R., Chen H., Song K., Price S., Heald R., Hewitt J.F.M., Zak M., Peck A., Orr C., Merchant M., Hoeflich K.P., Chan J., Luoh S.-M., Anderson D.J., Ludlam M.J.C., Wiesmann C., Ultsch M., Friedman L.S., Malek S., Belvin M. (2013) Mechanism of MEK inhibition determines efficacy in mutant KRAS- versus BRAF-driven cancers. Nature 501: 232-236.

Heard S.M., Grieser F., Barraclough C.G., Sanders J.V. (1983) The characterization of ag sols by electron microscopy, optical absorption, and electrophoresis. J. Colloid Interface Sci. 93: 545-555.

Hesse M., Meier H., Zeeh B., Dunmur R., Murray M. (2008) Spectroscopic methods in organic chemistry. Thieme Stuttgart.

Huang T., Xu X.-H.N. (2010) Synthesis and characterization of tunable rainbow colored colloidal silver nanoparticles using single-nanoparticle plasmonic microscopy and spectroscopy. J. Mater. Chem. 20: 9867.

Hubbard R., Rimington C. (1950) The biosynthesis of prodigiosin, the tripyrrylmethene pigment from Bacillus prodigiosus (Serratia marcescens). Biochem. J. 46(2): 220.

Huh J.E., Yim J.H., Lee H.K., Moon E.Y., Rhee D.K., Pyo S. (2007) Prodigiosin isolated from Hahella chejuensis suppresses lipopolysaccharide-induced NO production by inhibiting p38 MAPK, JNK and NF-KB activation in murine peritoneal macrophages. Int. Immunopharmacol. 7: 18251833.

Hyllested J.A.E., Palanco M.E., Hagen N., Mogensen K.B., Kneipp K. (2015) Green preparation and spectroscopic characterization of plasmonic silver nanoparticles using fruits as reducing agents. Beilstein J. Nanotechnol. 6: 293299.

Jiang H., Moon K.-S., Zhang Z., Pothukuchi S., Wong C.P. (2008) Variable Frequency Microwave Synthesis of Silver Nanoparticles. J. Nanoparticle Res. 8: 117-124.

Johnston H.L., Cuta F., Garrett A.B. (1933) The solubility of silver oxide in water, in alkali and in alkaline salt solutions. The amphoteric character of silver hydroxide. J. Am. Chem. Soc. 55: 2311-2325.

Katok K., Tertykh V., Yanishpolskii V. (2009) Synthesis and characterization of silver/silica nanostructures. Nanostructured Materials for Advanced Technological Applications, p. 207-210.

Kavitha R., Aiswariya S., Ratnavali C.M.G. (2010) Anticancer activity of red pigment from Serratia marcescens in human cervix carcinoma. Int. J. PharmTech. Res. 2: 784-787.

Kawasaki T., Sakurai F., Hayakawa Y. (2008) A prodigiosin from the roseophilin producer Streptomyces griseoviridis. J. Nat. Prod. 71: 1265-1267.

Kerker M. (1985) The optics of colloidal silver: something old and something new. J. Colloid Interface Sci. 105: 297-314.

Khanafari A., Assadi M.M., Fakhr F.A. (2006) Review of Prodigiosin, Pigmentation in Serratia marcescens. Online J. Biol. Sci. 6: 1-13. 
Kim D., Kim J.F., Yim J.H., Kwon S.-K., Lee C.H., Lee H.K. (2008) Red to red-the marine bacterium Hahella chejuensis and its product prodigiosin for mitigation of harmful algal blooms. J. Microbiol. Biotechnol. 1621-1629.

Knasmüller S., Parzefall W., Sanyal R., Ecker S., Schwab C., Uhl M., Mersch-Sundermann V., Williamson G., Hietsch G., Langer T., Darroudi F., Natarajan A.T. (1998) Use of metabolically competent human hepatoma cells for the detection of mutagens and antimutagens. Mutat. Res. Fundam. Mol. Mech. Mutagen 402: 185-202.

Knoll B., Keilmann F. (1999) Near-field probing of vibrational absorption for chemical microscopy. Nature 399: 7-10.

Kohler J.M., Fritzsche W. (2004) Nanotechnology: an introduction to nanostructuring techniques. Wiley-VCH, Weinheim.

Kreibig U., Vollmer M. (1995) Optical Properties of Metal Clusters. Springer.

Lai C., Lok A.S., Wu P., Chan G.C., Lin H. (1988) Doxorubicin versus no antitumor therapy in inoperable hepatocellular carcinoma. A prospective randomized trial. Cancer 62 : 479-483.

Lateef A., Akande M.A., Azeez M.A., Ojo S.A., Folarin B.I., Gueguim-Kana E.B., Beukes L.S. (2016a) Phytosynthesis of silver nanoparticles (AgNPS) using miracle fruit plant (Synsepalum dulcificum) for antimicrobial, catalytic, anticoagulant, and thrombolytic applications. Nanotechnol. Rev. 5: 507-520.

Lateef A., Akande M.A., Ojo S.A., Folarin B.I., Gueguim-Kana E.B., Beukes L.S. (2016b) Paper wasp nest-mediated biosynthesis of silver nanoparticles for antimicrobial, catalytic, anticoagulant, and thrombolytic applications. 3 Biotech. 6: 1-10.

Lateef A., Ojo S.A., Elegbede J.A., Azeez M.A., Yekeen T.A., Akinboro A. (2017) Evaluation of some biosynthesized silver nanoparticles for biomedical applications: hydrogen peroxide scavenging, anticoagulant and thrombolytic activities. J. Clust. Sci. 28: 1379-1392.

Lee M.-H., Kataoka T., Magae J., Nagai K. (1995) Immunomodulation of prodigiosin 25-C and concanamycin $B$. [in:] Animal cell technology: developments towards the 21st century $S E$ - 162. Eds. Beuvery E.C., Griffiths J.B., Zeijlemaker W.P. Springer Netherlands, p. 1025-1029.

Lee T., Lau T., Ng I. (2002) Doxorubicin-induced apoptosis and chemosensitivity in hepatoma cell lines. Cancer Chemother. Pharmacol. 49: 78-86.

Li X., Xu H., Chen Z.S., Chen G. (2011) Biosynthesis of nanoparticles by microorganisms and their applications. J. Nanomater. http://dx.doi.org/10.1155/2011/270974.

Lin D., Lin S., Liaw Y. (1997) Non surgical treatment of hepatocellular carcinoma. J. Gastroenterol. Hepatol. 12: 319S328.

Llagostera E., Soto-Cerrato V., Joshi R., Montaner B., Gimenez-Bonafé P., Pérez-Tomás R. (2005) High cytotoxic sensitivity of the human small cell lung doxorubicin-resistant carcinoma (GLC4/ADR) cell line to prodigiosin through apoptosis activation. Anticancer Drugs 16(4): 393-399.
Manikprabhu D., Lingappa K. (2013a) Microwave assisted rapid bio-based synthesis of gold nanorods using pigment produced by Streptomyces coelicolor klmp33. Acta Met. Sin. (Engl Lett) 26: 613-617.

Manikprabhu D., Lingappa K. (2013b) Antibacterial activity of silver nanoparticles against methicillin-resistant staphylococcus aureus synthesized using model streptomyces sp. pigment by photo-irradiation method. J. Pharm. Res. 6: 255-260.

Manikprabhu D., Lingappa K. (2014) Synthesis of silver nanoparticles using the Streptomyces coelicolor klmp33 pigment: An antimicrobial agent against extended-spectrum beta-lactamase (ESBL) producing Escherichia coli. Mater Sci. Eng. C 45: 434-437.

Maria B.S., Devadiga A., Kodialbail V.S., Saidutta M.B. (2014) Synthesis of silver nanoparticles using medicinal Zizyphus xylopyrus bark extract. Appl. Nanosci. 5: 755-762.

Maurice M. (2002) Bacterial pigments. Microbiologist 3: 10-12. Menges F. (2011) Spekwin32, Complete Documentation. p. 119.

Montaner B., Navarro S., Piqué M., Vilaseca M., Martinell M., Giralt E., Gil J., Pérez Tomás R., Pérez-Tomás R. (2000) Prodigiosin from the supernatant of Serratia marcescens induces apoptosis in haematopoietic cancer cell lines. Br. J. Pharmacol. 131: 585-593.

Montaner B., Perez-Tomas R. (2001) Prodigiosin-induced apoptosis in human colon cancer cells. Life Sci 68: 20252036.

Montaner B., Pérez-Tomás R. (2002) The cytotoxic prodigiosin induces phosphorylation of p38-MAPK but not of SAPK/JNK. Toxicol. Lett. 129: 93-98.

Mukherjee P., Roy M., Mandal B.P., Dey G.K., Mukherjee P.K., Ghatak J., Tyagi A.K., Kale S.P. (2008) Green synthesis of highly stabilized nanocrystalline silver particles by a non-pathogenic and agriculturally important fungus T. asperellum. Nanotechnology 19: 75103.

Mulvaney P. (1996) Surface plasmon spectroscopy of nanosized metal particles. Langmuir 12: 788-800.

Muthukrishnan L., Nanda A. (2013) Geno-toxic study of silver bio-nanoparticles toward Gram-positive and Gram-negative clinical isolates. J. Pharm. Res. 6: 725-729.

Nair V., Sambre D., Joshi S., Bankar A., Ravi Kumar A., Zinjarde S. (2013) Yeast-derived melanin mediated synthesis of gold nanoparticles. J. Bionanoscience 7: 159-168.

Narayanan K.B., Sakthivel N. (2011) Green synthesis of biogenic metal nanoparticles by terrestrial and aquatic phototrophic and heterotrophic eukaryotes and biocompatible agents. Adv. Colloid Interface Sci. 169: 59-79.

Ojo S.A., Lateef A., Azeez M.A., Oladejo S.M., Akinwale A.S., Asafa T.B., Yekeen T.A., Akinboro A., Oladipo I.C., Gueguim-Kana E.B., Beukes L.S. (2016) Biomedical and catalytic applications of gold and silver-gold alloy nanoparticles biosynthesized using cell-free extract of Bacillus safensis LAU 13: antifungal, dye degradation, anti-coagulant and thrombolytic activities. IEEE Trans. Nanobiosci. 15: 433-442. 
Pan M.-Y., Shen Y.-C., Lu C.-H., Yang S.-Y., Ho T.-F., Peng Y.T., Chang C.-C. (2012) Prodigiosin activates endoplasmic reticulum stress cell death pathway in human breast carcinoma cell lines. Toxicol. Appl. Pharmacol. 265(3): 325-334.

Pandey R., Chander R., Sainis K.B. (2007) Prodigiosins: a novel family of immunosuppressants with anti-cancer activity. Indian J. Biochem. Biophys. 44: 295.

Park G., Tomlinson J.T., Melvin M.S., Wright M.W., Day C.S., Manderville R.A. (2003) Zinc and copper complexes of prodigiosin: implications for copper-mediated doublestrand DNA cleavage. Org. Lett. 5: 113-116.

Poole C.P., Owens F.J. (2003) Introduction to nanotechnology. Collect. Manag. 21: 1-2.

Pradeep B.V., Pradeep F.S., Angayarkanni J., Palaniswamy M. (2013) Optimization and production of prodigiosin from Serratia marcescens MBB05 using various natural substrates. Asian J. Pharm. Clin. Res. 6: 34-41.

Qiu G.-H., Xie X., Xu F., Shi X., Wang Y., Deng L. (2015) Distinctive pharmacological differences between liver cancer cell lines HepG2 and Hep3B. Cytotechnology 67: 1-12. doi: 10.1007/s10616-014-9761-9.

Ramezani N., Ehsanfar Z., Shamsa F., Amin G., Shahverdi H.R., Esfahani H.R.M., Shamsaie A., Bazaz R.D., Shahverdi A.R. (2008) Screening of medicinal plant methanol extracts for the synthesis of gold nanoparticles by their reducing potential. Z. Naturforsch B 63: 903-908.

Rapoport H., Holden K.G. (1962) The synthesis of prodigiosin. J. Am. Chem. Soc. 84: 635-642.

Rokem J.S., Weitzman P. (1987) Prodigiosin formation by Ser ratia marcescens in a chemostat. Enzyme Microb. Technol. 9: 153-155.

Rubilar O., Rai M., Tortella G., Diez M.C., Seabra A.B., Durán N. (2013) Biogenic nanoparticles: Copper, copper oxides, copper sulphides, complex copper nanostructures and their applications. Biotechnol. Lett. 35: 1365-1375.

Samrot A.V., Chandana K., Senthilkumar P. (2011) Optimization of prodigiosin production by Serratia marcescens SU-10 and evaluation of its bioactivity Optimization of prodigiosin production by Serratia marcescens $S U-10$ and evaluation of its bioactivity. Int. Res. J. Biotechnol. 2: 128-133.

Sastry M., Ahmad A., Islam Khan M., Kumar R. (2003) Biosynthesis of metal nanoparticles using fungi and actinomycete. Curr. Sci. 85: 162-170.

Shankar S.S., Rai A., Ahmad A., Sastry M. (2004) Rapid synthesis of $\mathrm{Au}, \mathrm{Ag}$, and bimetallic Au core- $\mathrm{Ag}$ shell nanoparticles using Neem (Azadirachta indica) leaf broth. J. Colloid Interface Sci. 275: 496-502.

Siegel R., Naishadham D., Jemal A. (2013) Cancer statistics, 2013. CA Cancer J. Clin. 63: 11-30.

Skehan P., Storeng R., Scudiero D., Monks A., McMahon J., Vistica D., Warren J.T., Bokesch H., Kenney S., Boyd M.R. (1990) New colorimetric cytotoxicity assay for anticancer-drug screening. J. Natl Cancer Inst. 82: 1107-1112.

Slater H., Crow M., Everson L., Salmond G.P.C. (2003) Phosphate availability regulates biosynthesis of two antibiotics, prodigiosin and carbapenem, in Serratia via both quorum sensing dependent and independent pathways. Mol. Microbiol. 47: 303-320.

Sönnichsen C., Franzl T., Wilk T., Von Plessen G., Feldmann J. (2002) Plasmon resonances in large noble-metal clusters. New J. Phys. 4: 93.

Suber L., Sondi I., Matijević E., Goia D.V. (2005) Preparation and the mechanisms of formation of silver particles of different morphologies in homogeneous solutions. J. Colloid Interface Sci. 288: 489-495.

Thakkar K.N., Mhatre S.S., Parikh R.Y. (2010) Biological synthesis of metallic nanoparticles. Nanomedicine Nanotechnology Biol. Med. 6: 257-262.

Thomsen R., Christensen M.H. (2006) MolDock: a new technique for high-accuracy molecular docking. J. Med. Chem. 49: 3315-3321.

Venil C.K. (2009) An insightful overview on microbial pigment, prodigiosin. Electr. J. Biol. 5(3): 49-61.

Wang D., Boerner S.A., Winkler J.D., LoRusso P.M. (2007) Clinical experience of MEK inhibitors in cancer therapy. Biochim. Biophys. Acta 1773: 1248-1255.

Wang Z., Liu J., Chen X., Wan J., Qian Y. (2004) A simple hydrothermal route to large-scale synthesis of uniform silver nanowires. Chemistry 11: 160-163.

Wasserman H.H., Rodgers G.C., Keith D.D. (1969) Metacycloprodigiosin, a tripyrrole pigment from Streptomyces longisporus ruber. J. Am. Chem. Soc. 91: 1263-1264.

Weiss C.M. (1949) Spectrophotometric and chromatographic analyses of the pigment produced by members of the genus serratia. J. Cell Comp. Physiol. 34: 467-492.

Williams R.P. (1973) Biosynthesis of prodigiosin, a secondary metabolite of Serratia marcescens. Appl. Microbiol. 25: 396-402.

Williams R.P., Gott C.L., Green J.A. (1961) Studies on pigmentation of Serratia marcescens V: accumulation of pigment fractions with respect to length of incubation time1. J. Bacteriol. 81: 376.

Williams R.P., Gott C.L., Qadri S.M., Scott R.H. (1971) Influence of temperature of incubation and type of growth medium on pigmentation in Serratia marcescens. J. Bacteriol. 106: 438-443.

Williams R.P., Green J.A., Rappo-Port D.A. (1956) Studies on pigmentation of Serratia marcescens. I. Spectral and paper chromatographic properties of prodigiosin. J. Bacteriol. 71: 115-120.

Wolber G., Langer T. (2005) LigandScout: 3-D pharmacophores derived from protein-bound ligands and their use as virtual screening filters. J. Chem. Inf. Model 45: 160-169.

Xia Y., Halas N.J. (2011) Shape-controlled synthesis and surface plasmonic properties of metallic nanostructures. MRS Bull 30: 338-348. doi: 10.1557/mrs2005.96

Xu F., Xia S., Yang Q. (2011) Strategy for obtaining inexpensive prodigiosin production by Serratia marcescens. [in:] $3^{\text {rd }}$ International Conference on Chemical, Biological and Environmental Engineering, p. 32-36. 
Yamamoto C., Takemoto H., Kuno K., Yamamoto D., Tsubura A., Kamata K., Hirata H., Yamamoto A., Kano H., Seki T., Inoue K. (1999) Cycloprodigiosin hydrochloride, a new $\mathrm{H}(+) / \mathrm{Cl}(-)$ symporter, induces apoptosis in human and rat hepatocellular cancer cell lines in vitro and inhibits the growth of hepatocellular carcinoma xenografts in nude mice. Hepatology 30: 894-902. doi: 10.1002/hep. 510300417.
Yang T., Lin Y., Chen J., Wang H., Wang C. (2000) Phase II study of gemcitabine in patients with advanced hepatocellular carcinoma. Cancer 89: 750-756.

Zaki S., Elkady M.F., Farag S., Abd-El-Haleem D. (2012) Determination of the effective origin source for nanosilver particles produced by Escherichia coli strain S78 and its application as antimicrobial agent. Mater Res. Bull. 47: 4286-4290. 